\title{
A Comprehensive Insight into the Role of Exosomes in Viral Infection: Dual Faces Bearing Different Functions
}

\author{
Mabroka H. Saad ${ }^{1}$, Raied Badierah ${ }^{2,3}\left(\mathbb{D}\right.$, Elrashdy M. Redwan ${ }^{1,2}\left(\mathbb{D}\right.$ and Esmail M. El-Fakharany ${ }^{1, *(\mathbb{D})}$ \\ 1 Protein Research Department, Genetic Engineering and Biotechnology Research Institute (GEBRI), \\ The City of Scientific Research and Technological Applications (SRTA-City), New Borg EL Arab, \\ Alexandria 21934, Egypt; mabrokasaad89@gmail.com (M.H.S.); rredwan@gmail.com (E.M.R.) \\ 2 Biological Science Department, Faculty of Science, King Abdulaziz University, Jeddah 21589, Saudi Arabia; \\ rbadierah@kau.edu.sa \\ 3 Medical Laboratory, King Abdulaziz University Hospital, King Abdulaziz University, \\ Jeddah 21589, Saudi Arabia \\ * Correspondence: esmailelfakharany@yahoo.co.uk
}

check for updates

Citation: Saad, M.H.; Badierah, R.; Redwan, E.M.; El-Fakharany, E.M. A Comprehensive Insight into the Role of Exosomes in Viral Infection: Dual Faces Bearing Different Functions. Pharmaceutics 2021, 13, 1405. https://doi.org/10.3390/ pharmaceutics13091405

Academic Editor: María Socorro Espuelas Millán

Received: 7 August 2021

Accepted: 2 September 2021

Published: 4 September 2021

Publisher's Note: MDPI stays neutral with regard to jurisdictional claims in published maps and institutional affiliations.

Copyright: (c) 2021 by the authors. Licensee MDPI, Basel, Switzerland. This article is an open access article distributed under the terms and conditions of the Creative Commons Attribution (CC BY) license (https:/ / creativecommons.org/licenses/by/ $4.0 /)$.

\begin{abstract}
Extracellular vesicles (EVs) subtype, exosome is an extracellular nano-vesicle that sheds from cells' surface and originates as intraluminal vesicles during endocytosis. Firstly, it was thought to be a way for the cell to get rid of unwanted materials as it loaded selectively with a variety of cellular molecules, including RNAs, proteins, and lipids. However, it has been found to play a crucial role in several biological processes such as immune modulation, cellular communication, and their role as vehicles to transport biologically active molecules. The latest discoveries have revealed that many viruses export their viral elements within cellular factors using exosomes. Hijacking the exosomal pathway by viruses influences downstream processes such as viral propagation and cellular immunity and modulates the cellular microenvironment. In this manuscript, we reviewed exosomes biogenesis and their role in the immune response to viral infection. In addition, we provided a summary of how some pathogenic viruses hijacked this normal physiological process. Viral components are harbored in exosomes and the role of these exosomes in viral infection is discussed. Understanding the nature of exosomes and their role in viral infections is fundamental for future development for them to be used as a vaccine or as a non-classical therapeutic strategy to control several viral infections.
\end{abstract}

Keywords: extracellular vesicles (EVs); pathogenesis and immune modulation; immune evasion

\section{Introduction}

Extracellular vesicles (EVs) are a heterogeneous group of lipid-bound vesicles, which are derived from the plasma membrane or endosomes and secreted by almost all cell types into the extracellular lumen [1,2]. EVs are categorized into three main subtypes: exosomes (30 to $100 \mathrm{~nm})$, microvesicles ( 100-1000 nm), and apoptotic bodies ( 500-4000 nm) based on their size, content, biogenesis, and function. These EVs subtypes have been detected in different biological fluids such as cerebrospinal fluid, saliva, blood, breast milk, ascetic fluid, amniotic fluid, seminal fluid, and urine [3,4]. At first, EVs are considered as cell debris, but recently they have emerged as important mediators in intercellular communication and they are involved in numerous physiological and pathological processes $[5,6]$ such as inflammation and immune response [7], neuron-glia communication and myelination [8,9], infection [10,11], and cancer [12,13]. In addition, EVs play a crucial role in viral infection influencing viral entry, transmission, and immune evasion [14-17], as they serve as an important intercellular communication tool between uninfected and infected cells [15,18]. Viruses and EVs have common biogenesis pathways, so they are considered to be close relatives. Moreover, EVs shed from infected cells can either prompt an antiviral response or, on the contrary, increase viral infection [19]. 
In recent decades, exosome is one of the EVs that received great attention in different fields such as gene and drug delivery and prognostic and diagnostic biomarkers. Although the Greek word "exosome" comes from the "Exo" ("outside") and "soma" ("body"), the accurate meaning is not understood immediately from the word's parts and the term needs more explanation to be clear to non-specialists. The term "exosome" was first given to mobile DNA elements, then Mitchell and colleagues used this term to name an RNA processing body in the cell [20]. In the early 1980s, two teams of researchers discovered small vesicles formed via inward budding inside of the endosomal membrane while studying the reticulocytes culture media [21-23]; then at the end of the 1980s, Dr. Rose Johnstone gave the term "exosomes" to these small vesicles [24,25]. The International Society for Extracellular Vesicles (ISEV) recommended the term "extracellular vesicles" on the nomenclature of non-replicative, lipid bilayer naturally released vesicles from different cells as this term has a very clear meaning to non-specialists and specialists alike [26]. Regardless of the argument between scientists on the nomenclature and their bias to specific terms as we observed in different reviews in the literature, we will focus our discussion on the role of exosomes in viral infection.

\section{Extracellular Vesicles Overview}

Extracellular vesicles are considered one of the intercellular communication mechanisms derived from different cell types and they act as crosstalk between cells. These cell-derived membrane vesicles have a complex cargo containing proteins [27], lipids [28], and nucleic acids [29]. Different studies hypothesized that these cargoes are delivered to both local and distant cells, at which they exert their function. EVs are primarily classified into three main classes: exosomes (30 to $100 \mathrm{~nm}$ ), microvesicles ( 100-1000 nm), and apoptotic bodies ( 500-4000 nm) and the differences between EVs are summarized as follows; apoptotic bodies are the largest extracellular vesicles $(\sim 500-4000 \mathrm{~nm})$ that are observed during programmed cell death or apoptosis [30]. Apoptosis progresses through a series of stages which end with cell disintegration and enclosing cellular content in distinct membranous vesicles, named apoptosome or apoptotic bodies. In addition, the cargo of apoptotic bodies is characterized by the presence of different cellular organelles and/or nuclear content [31], [32]. Microvesicles (MV), also termed microparticles or ectosomes, emerged from the outward budding of the plasma membrane and have $100-1000 \mathrm{~nm}$ in size [33]. MVs' size, content, their formation from the plasma membrane, and their membrane-specific antigens, are the most distinguishing factor from apoptotic bodies [25]. Exosomes (our interesting point) are the smallest extracellular secretory nanovesicles with an estimated density between 1.13 and $1.19 \mathrm{~g} / \mathrm{mL}$ and their size ranges from 30 to $100 \mathrm{~nm}$ [34]. Finally, the International Society of Extracellular Vesicles (ISEV) has recommended the generic term "EVs" for the vesicles derived from the cell due to the absence of specific markers and purification challenges for each EV subtype [26].

In recent decades, exosomes have acquired a large interest owing to their active role in the communication process between the cells [35]. They are derivatives of the cell's endosomal process and form the multivesicular nanobody that tempers with the plasma membrane to excrete exosomes to the extracellular space [36]. Virtually, all cell types can release these nano-vesicles with varying levels, upon the fusion of the plasma membrane with multivesicular bodies [37-39]. Recently and contrary to what was initially thought, it is well established that exosomes are not the cell's trash bags while they serve as imperative nano-vehicles for the transferring of specific viral cargo to inside and outside the host cells [40]. Based on their viral cargo, these exosomes can facilitate certain intercellular communication pathways $[7,41]$. Despite the mode of how this viral cargo is selected for packaging into these nano-vesicles intended for secretion, it remains unclear, and the endosomal membranes are supposed to play an essential role in this pathway [42,43]. After inward budding from early endosomal compartments, exosomes can form by packaging into the late endosomal membranes [22]. Then, both late endosome membranes and plasma membrane fuse leading to the release of the exosomes into the outside space of the cells. 
It was established that exosomes exist in most secretions, including plasma, serum, saliva, tears, urine, semen, sweat, breast milk, and cerebrospinal fluid; besides, they are secreted in the supernatant of cell cultures [22], which is not limited to the vertebrates but is present in most invertebrates animals [44,45]. Depending on the status of the host cells, exosomes are composed of variable contents, and many studies established that exosomes can encapsulate multiple types of lipids and several kinds of proteins. These proteins include proteins that are complexed in vesicle formation, integral membrane proteins, membrane fusion-related proteins, proteins associated with cell metabolism and the cytoskeleton process, both classes I and II ingredients of the major histocompatibility complexes (MHC), and the cell surface proteins integrated with oncogenesis process [46,47]. Furthermore, most types of nucleic acids like DNA, long non-coding RNAs (lncRNAs), miRNA, and mRNA have been identified to be involved in the structure of exosomes $[48,49]$. Additionally, membranes of exosomes play an important role in the protection of their viral cargo from degradation by host enzymes; besides, they can provide other smart characteristics including high biocompatibility, overcome biological barriers, and low immunogenicity [50,51]. Exosomes provide precise intercellular communication by regulating the various levels of pathological and physiological processes by transmitting biological signals between the host cells. Besides the role of exosomes in pathogenesis, many specific components in exosomes can play critical roles in anti-viral activities via stimulating the antiviral immune responses or through inhibition of viral replication directly [52]. All these features of nano-vesicles encourage researchers and scientists to highlight the importance of exosomes.

\section{Molecular Structure of Exosomes}

Exosomes are multiform nano-vesicles with a diameter ranging from 30 to $100 \mathrm{~nm}$ which have a cup-shaped appearance on scanning electron microscopy. Exosomes classically consist of luminal cargo, including nucleic acids (DNA, RNA), lipid-derivatives, proteins, peptides, and amino acids enclosed in a lipid bilayer membrane (Figure 1). Exosomes act as transport vehicles and protective barriers to the luminal cargo from the tough extracellular surroundings [4]. The composition of this luminal cargo contains derivatives of cytosolic proteins from the donor host cell [53,54]. Advanced proteomic analysis techniques together with the high-resolution investigation by electron microscopy revealed the structure of exosomes released from various host cells [46,55]. The structure of the lipid bilayer derivatives of exosomes varies from the structure of the lipid of the plasma membrane of the host cell [56]. Exosomes are comprised of a rich level of lipids including sphingolipids, PS, cholesterol, and primarily ceramide [57]. Remarkably, membranes of exosomes do not involve lysophosphatidic acid [58], despite that lysophosphatidic acid has been identified in intraluminal vesicles and is supposed to be essential, together with Alix, for their formation [59]. Additionally, lipid membranes of exosomes also comprise subdomains of detergent-resistant lipid, i.e., subdomains enriched in sphingolipids and cholesterol (rafts). These lipid rafts are also enriched in numerous proteins such as flotillins that appear to bind to rafts [4]. Meanwhile, exosomes are containing protein derivatives including membrane fusion and transport proteins, multivesicular body formation proteins, tetraspanins, adhesion proteins, heat shock proteins, antigen presentation (MHC class molecules), and lipoproteins [54,60]. According to the type of infections, the composition of exosomal membranes is varied including modifications in the content of lipids and proteins and even spatial structure inversions. The quantity of exosomal proteins has been exposed to be changed under conditional stress or pathological status [61]. 


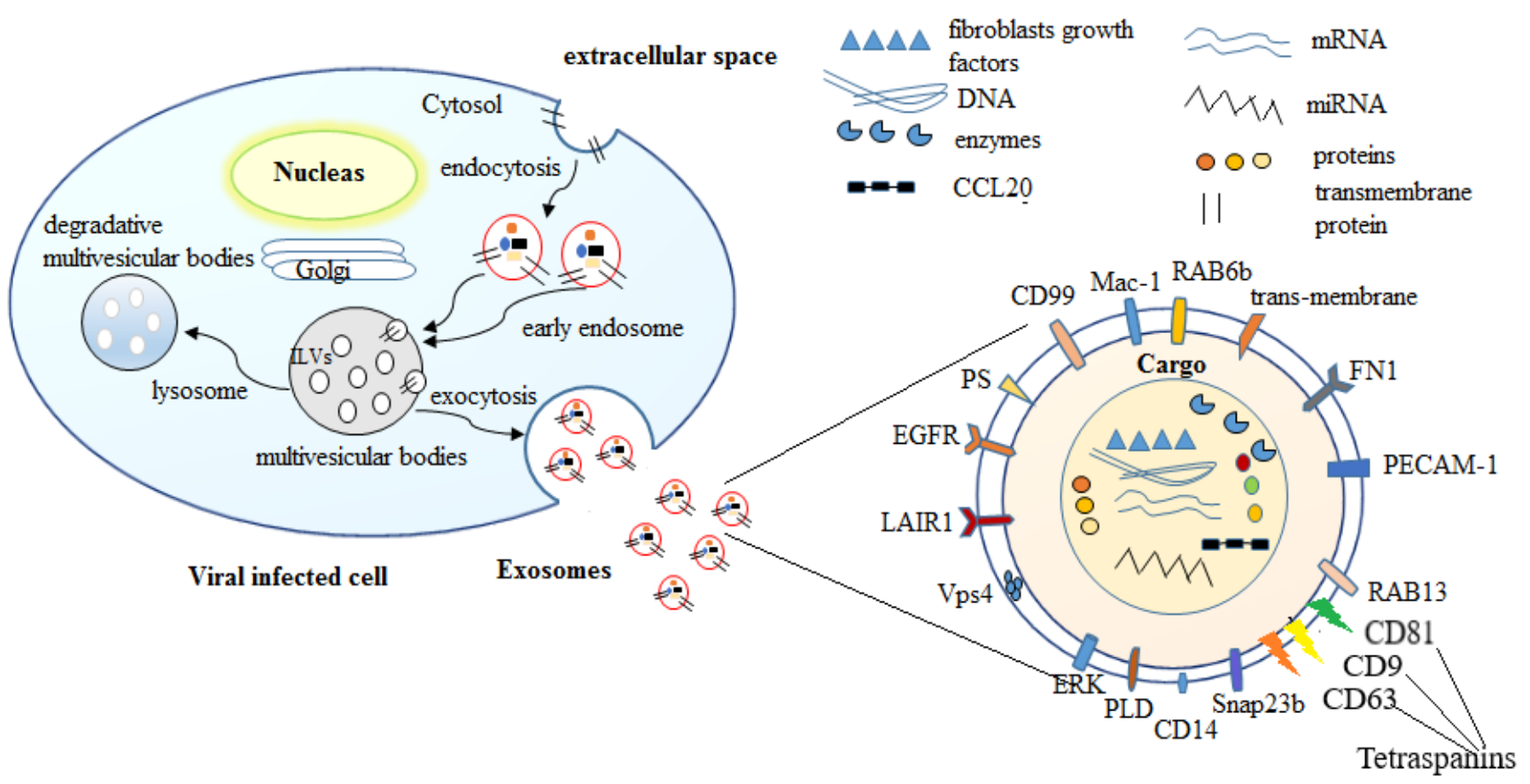

Figure 1. Schematic representation of formation and molecular structure of exosomes. Exosomes are formed by the trafficking of endocytosed proteins to originate the early endosomes through invagination of the plasma membrane. Early endosomes invaginate to generate intraluminal vesicles (ILVs) that are stored inside the multivesicular bodies. These bodies can then fuse with the plasma membrane to generate exosomes which are released into the extracellular space. These exosomes contain proteins, enzymes, nucleic acids (DNA mRNAs, and miRNAs), and lipids. This cargo is surrounded by lipid bilayer membranes which contain some components such as EGFR (epidermal growth factor receptor), LAIR1 (leukocyte-associated immunoglobulin-like receptor 1), Vps4 (Vacuolar protein sorting-associated protein 4), ERK (extracellular-signal-regulated kinase), PLD (phospholipase D), CD14 (cluster of differentiation 14), Snap23 (synaptosomalassociated protein 23b), RAB13 (Ras-related protein Rab-13), PECAM1 (platelet/endothelial cell adhesion molecule 1), FN1 (fibronectin 1), RAB6b (Ras-related protein Rab-6B), Mac-1 (macrophage-1 antigen), CD99 (cluster of differentiation 99), and PS (phosphatidylserine).

Furthermore, the outer surface of exosomes also contains glycan and polysaccharide derivatives, mainly include of mannose, polylactosamine, $\alpha-2,3$ - and $\alpha$-2,6-sialic acids, and complex $\mathrm{N}$-linked glycans $[62,63]$. Exosomes also contain nucleic acids including DNA and RNA such as miRNAs, some non-coding RNAs, and mRNAs [64]. Consequently, exosomes are categorized as bioactive nano-vesicles that contribute to intercellular communication by transferring their cargo to other host cells. By these facts, exosomes are involved in enormous pathways of biological processes, such as but not limited to those involved in the immunomodulatory process [65]. Furthermore, exosome cargo can contain some components of pathogenic microbes that are capable of enhancing immune and proinflammatory response [66]. This is because exosomes are formed intracellularly by the invagination process of the endosome membrane through the generation of an intraluminal vesicles bud into the multivesicular bodies in the cytosol. This invagination process seizes a large quantity of cytosol, involving the derivatives of enclosed proteins and RNA. Whereas exosomes comprise a collective amount of proteins regardless of host cell origin and topical investigations have revealed a cell kind-specific signature in exosomes [54].

\section{Exosomes Biogenesis and Their Role in the Immune Response to Viral Infection}

Exosomes generated by the endosomal route and this process initiated with inward budding of the plasma membrane resulted in early endosomes formation, followed by invagination of early endosomes membrane and enclosed the surrounding lumina with cytoplasmic content resulted in intraluminal vesicles (ILVs) formation [67]. Finally, the late endosome comprised dozens of ILVs which are termed as multivesicular bodies (MVBs). 
The fate of MVBs is the fusion with the plasma membrane that resulted in exosomes releasing, being transported to lysosomes for degradation of their cargo, or being delivered to the trans-Golgi system for endosome recycling [68]. The factors that control the fate or direction of MVB are not completely understood; however, previous studies reported that cholesterol-enriched MVBs undergo exosome releasing while the others undergo degradation. In addition, the two Rab family constituents, Rab27A and B, induce MVBs translocation to cell margin then sensitive factor attachment protein receptor (SNARE) complex facilities MVBs fusion with the cell membrane to release exosomes [69,70]. Endosomalsorting complex required for transport (ESCRT) plays a crucial role in exosome biogenesis and releasing process [71]. ESCRT system involves four complexes known as ESCRT-0, ESCRT-I, ESCRT-II, and ESCRT-III with associated proteins (Tsg101, ALIX, and VPS4). During the biogenesis process, each complex has the role as follows: ESCRT-0 is recruited by ubiquitinated cargo to the lipid domain and initiates the pathway, ESCRT-I and ESCRT-II complexes trigger the deformation of membrane resulting in buds or stable membrane neck and this is also responsible for the recruitment of Vps4 complex to ESCRT-III which separates or scissors from the cytoplasmic membrane [72]. In addition, several studies discussed exosome biogenesis and their cargo loading in the route of ESCRT-independent pathway, which comprises lipids and associated protein as tetraspanin [73]. While proteins required ESCRT complexes to be loaded into exosomes, RNA sorting through a process depending on self-organizing lipid and cargo domains as a specific RNA sequence has an affinity for the phospholipid bilayer, which is influenced by hydrophobic modifications, lipid rafts, and sphingosine concentration in membrane rafts [74].

These released nano-vesicles may enhance immune response and present antigens of viral pathogens through a cellular immune response. Meckes and Raab-Traub [15] revealed that exosomes have numerous features in common with enveloped viruses such as biogenesis, biophysical characteristics, and sorting in cells. Recent studies defined the nano-vesicle-mediated intercellular transfer of functional cellular proteins; mRNAs and miRNAs have exposed further similarities between viruses and cellular nano-vesicles. They also showed that the editing enzyme of apolipoprotein B mRNA catalytic subunit 3G, -a cytidine deaminase that contributes to the antiviral cellular response against retroviruses, might be preventing HIV-1 replication through an accumulation of exosomes in neighboring host cells. Izquierdo-Users et al. [75] revealed that HIV-1 sorts all particles and antigens in exosome-like vesicles after fusing with DCs uses. They revealed also that HIV-1 uses a cluster of DCs as a transit location in the non-replicative phase. Van Dongen et al. [76] showed that exosomes provoke viral infection through bearing viral antigens and transferring their cargos to CD4 + T cells (Table 1). 
Table 1. Exosomes' biogenesis and their roles in pathogenesis, medical usefulness, and applications in viral infection.

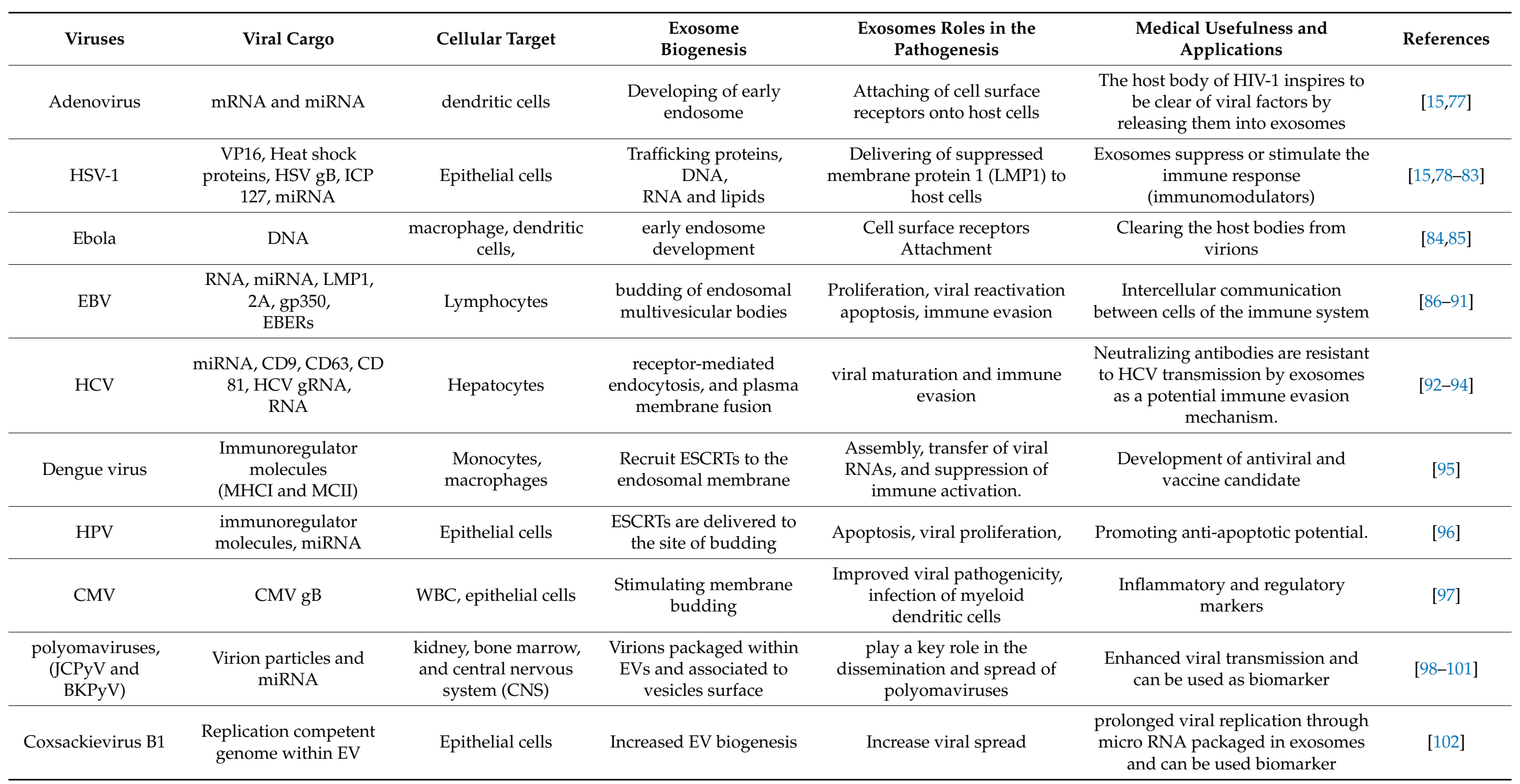


Table 1. Cont

\begin{tabular}{|c|c|c|c|c|c|c|}
\hline Viruses & Viral Cargo & Cellular Target & $\begin{array}{c}\text { Exosome } \\
\text { Biogenesis }\end{array}$ & $\begin{array}{c}\text { Exosomes Roles in the } \\
\text { Pathogenesis }\end{array}$ & $\begin{array}{c}\text { Medical Usefulness and } \\
\text { Applications }\end{array}$ & References \\
\hline Chikungna virus & apoptotic bodies & $\begin{array}{l}\text { Skeletal muscles, brain, } \\
\text { and liver cells }\end{array}$ & $\begin{array}{l}\text { hijacking apoptotic } \\
\text { bodies }\end{array}$ & $\begin{array}{l}\text { Infectious virions hijacking } \\
\text { apoptotic bodies. Increased viral } \\
\text { spread }\end{array}$ & $\begin{array}{l}\text { Increased viral spread and can be } \\
\text { used as biomarker }\end{array}$ & [103] \\
\hline \multirow{2}{*}{ ZIKV } & $\begin{array}{l}\text { Macrophage-derived } \\
\text { exosomes }\end{array}$ & \multirow{2}{*}{$\begin{array}{l}\text { Brain, skin, placenta, } \\
\text { retina, testis, and } \\
\text { kidney cells }\end{array}$} & \multirow{2}{*}{$\begin{array}{l}\text { Infection significantly } \\
\text { increases EV formation }\end{array}$} & $\begin{array}{l}\text { Induction of placental } \\
\text { proinflammatory cytokine } \\
\text { production. }\end{array}$ & \multirow{2}{*}{$\begin{array}{l}\text { EVs derived from the semen of a } \\
\text { ZIKV-infected patient inhibited } \\
\text { ZIKV and delivering therapeutics } \\
\text { across brain barriers }\end{array}$} & \\
\hline & $\begin{array}{l}\text { EV-bound ZIKV-RNA } \\
\text { and E-protein }\end{array}$ & & & $\begin{array}{l}\text { Increased ZIKV transmission } \\
\text { across neurons }\end{array}$ & & [106] \\
\hline HIV & $\begin{array}{l}\text { Cytoskeletal proteins } \\
\text { (Actin, Tubulin, Lamin, } \\
\text { Myosin)miRTAR, } \\
\text { miRNA, } \\
\text { Nef }\end{array}$ & Lymphocytes & $\begin{array}{l}\text { ESCRT I and IIenhance } \\
\text { membrane } \\
\text { budding }\end{array}$ & $\begin{array}{l}\text { Induce proinflammatory } \\
\text { cytokines, inhibition of } \\
\text { apoptosis, } \\
\text { increased } \\
\text { susceptibility of naïve T } \\
\text { cells, downregulation } \\
\text { of CD4 } \\
\text { and MHC I, Support viral } \\
\text { reproduction and } \\
\text { pathogenesis }\end{array}$ & $\begin{array}{c}\text { Analytical indicators in HIV-1, } \\
\text { antiviral activity }\end{array}$ & [107-111] \\
\hline HBV & HBsAg, DNA, RNA & Hepatocytes & $\begin{array}{l}\text { Multivesicular bodies } \\
\text { fuse with the plasma } \\
\text { membrane and secrete } \\
\text { exosomes }\end{array}$ & $\begin{array}{l}\text { Innate immunity evasion, } \\
\text { transmission regulators }\end{array}$ & $\begin{array}{l}\text { Drug delivery candidates for the } \\
\text { targeted or systematic vehicle to } \\
\text { particular organs or tissues }\end{array}$ & {$[14,112,113]$} \\
\hline
\end{tabular}


Table 1. Cont

\begin{tabular}{|c|c|c|c|c|c|c|}
\hline Viruses & Viral Cargo & Cellular Target & $\begin{array}{l}\text { Exosome } \\
\text { Biogenesis }\end{array}$ & $\begin{array}{l}\text { Exosomes Roles in the } \\
\text { Pathogenesis }\end{array}$ & $\begin{array}{l}\text { Medical Usefulness and } \\
\text { Applications }\end{array}$ & References \\
\hline HAV & $\begin{array}{l}\text { HAV particles, enzymes, } \\
\text { HAV gRNA, }\end{array}$ & Hepatocytes & $\begin{array}{c}\text { Transport of ESCRT III, } \\
\text { VPS4B, and ALIX. } \\
\text { through } \\
\text { endosomal-sorting } \\
\text { complexes }\end{array}$ & $\begin{array}{l}\text { Increasing viral infectivity, } \\
\text { innate immunity evasion, } \\
\text { intercellular communications }\end{array}$ & $\begin{array}{l}\text { Drug delivery candidates for the } \\
\text { targeted or systematic vehicle to } \\
\text { particular organs or tissues }\end{array}$ & [114] \\
\hline $\begin{array}{l}\text { Rift Valley fever } \\
\text { virus }\end{array}$ & $\begin{array}{l}\text { Viral proteins, miRNA, } \\
\text { mRNA }\end{array}$ & WBC & $\begin{array}{l}\text { ESCRTs } \\
\text { enhance membrane } \\
\text { budding }\end{array}$ & $\begin{array}{l}\text { Immune evasion, apoptosis, } \\
\text { enhance viral infectivity }\end{array}$ & Analytic indicators & [115] \\
\hline $\begin{array}{l}\text { human } \\
\text { T-lymphotropic } \\
\text { virus }\end{array}$ & $\begin{array}{l}\text { mRNA, miRNA, } \\
\text { trans-activator protein }\end{array}$ & Lymphocytes & $\begin{array}{c}\text { ESCRTs } \\
\text { Stimulate membrane } \\
\text { budding }\end{array}$ & $\begin{array}{l}\text { Activate cytokines, damage to } \\
\text { neurons, increase viral } \\
\text { replication }\end{array}$ & $\begin{array}{l}\text { Contribute to the pathology of the } \\
\text { viral infection }\end{array}$ & [116-118] \\
\hline HHV-8 & RNA, miRNA & $\begin{array}{l}\text { endothelial } \\
\text { cells, WBC }\end{array}$ & $\begin{array}{l}\text { budding of endosomal } \\
\text { multivesicular bodies }\end{array}$ & $\begin{array}{l}\text { cell metabolism, immune } \\
\text { modulation }\end{array}$ & $\begin{array}{l}\text { Intercellular communication } \\
\text { between cells of the immune system }\end{array}$ & {$[119,120]$} \\
\hline
\end{tabular}


Furthermore, some viruses might also operate with the machinery of vesicular trafficking for their assembly, egress, and uptaking [17,121]. Recent studies revealed that HIV-1 has been shown to exploit the lipid raft domains, endosomal sorting complex required for transport-II (ESCRT), and Rab GTPases constituents, all of which are included in exosome biogenesis [122,123]. Exosomal tetraspanins, particularly CD81 and CD63, interact with egress HIV-1 Gag to assist in virion. Mori et al. [124] revealed that Human herpesvirus 6 (HHV-6) virions have been established to use the same pathway of induction for the formation of multivesicular bodies and egress happens by an exosomal release pathway. Intraluminal vesicles transfer plasma membrane invaginations to the endosomal set via clathrin-independent and clathrin-mediated endocytosis process (back fusion process) making exosomes capable of harboring both extracellular and intracellular ingredients $[80,125]$. Exosomes are characterized by their ability to provide snapshots of the microenvironment, making them serve as an effective resource of biomarkers. This exosome feature is owing to the great cross-over between viral entry and normal macromolecule entry, exosome biogenesis, release, and cycling within the host cell $[80,125]$. Furthermore, there are other enriched ingredients in exosomes such as lipid raft-associated proteins (proteins included in membrane trafficking including the tetraspanins CD63, CD9, and CD81, transferrin, and caveolins) which have been shown to bind to ESCRT machinery [15,126,127]. One method for viral intonation of exosome secretion is by directly binding with the machinery included in exosome biogenesis (ESCRT-dependent method). However, ESCRT-independent processes can also occur by which lipids, proteins, and nucleic acids can originate from the endosomal pathway mechanism. For instance, oligodendrocytes initiate exosome formation through the ceramide machinery pathway [128], whereas other host cell kinds depend on the oligomerization of tetraspanin complexes [129,130]. Additionally, although the reduction of some ESCRT ingredients might revoke exosome formation, it does not entirely knock it out [131,132]. Specific candidates of the Rab GTPases family, a family of highly conserved proteins that regulate many processes of membrane fusion and vesicular trafficking in eukaryotes, are also concluded in exosome production as indicated by their extraordinary richness in extracted exosomes $[11,133]$. Recently, it has been shown that activation of Rab GTPases and interfering with their levels enhances the secretion of exosomes from host cells. Depending on the kind of host cells, Rab5, Rab7, Rab11, Rab27, and Rab35 were all associated with the secretion process. It was found that overexpression of Rab5 inhibits the development of endocytosed material from early endosomes, leading to markers reduction of exosomal releases such as CD63, Alix, and syndecan, and this negative impact was liberated by the Rab7 overexpression [134]. Being GTPases, each Rab stimulation is dependent on the calcium influx process such as in the event of Rab 11 in the K562 cells, which might include SNARE proteins [135-137]. Overall, there are many players inside the host cell that donate to the endosomal process and, eventually, to the secretion of exosomes, promoting emphasis on the significance of this process in standard biology. In this way, viral pathogens also have other advanced machinery modules to involve their viral cargo at every step of exosome biogenesis [17].

\section{Exosomes Purification and Characterization}

\subsection{Ultracentrifugation Techniques}

Ultracentrifugation (UC) is considered the gold standard isolation technique for exosomes and the most widely applied isolation method for exosome extraction and separation. Separation of desired components using ultracentrifugation technique is mainly based on the difference in size and density of each component in mixture solution, so large-dose sample constituents which significantly differ in sedimentation coefficient can be effectively separated using this method [138]. Johnstone et al. [139] first used the ultracentrifugation technique to separate exosomes from reticulocytes and Thery et al. [140] optimized this method. The ultracentrifugation technique involves two main steps: (1) getting rid of large-size extracellular vesicles, cell debris, and dead cells through a sequence of continuous low-medium speed centrifugation, followed by separating exosomes at 
higher speed centrifugation $(100,000 \times g)$. In addition, studies have reported that the purity and yield of target exosomes are affected by centrifugal parameters including centrifugation force, time, and rotor type [138,141]. This method does not need to label exosomes, which can avoid cross-contamination, but it is not conducive to downstream analysis due to its time consumption, high cost, structural damage, aggregation into blocks, and lipoprotein co-separation [142]. Furthermore, the density gradient centrifugation is usually applied within ultracentrifugation to enhance the purity of the exosomes. The density gradient centrifugation is divided into two main classes: one of them using sucrose as a gradient medium that is widely applied in research. However, this method is not successful in the separation of retroviruses and exosomes which nearly have the same density and size. For this purpose, Cantin et al. [143] reported that the iodixanol gradient is effective in the exosomes separation from HIV-1- infected cells with high purity yield. Although, the exosome purity is the advantage of the density gradient centrifugation; decreasing the sedimentation rate of exosomes due to the high viscosity of sucrose is a point against this technique [144].

\subsection{Polymer Precipitation}

This technique was first used to separate viruses [145]. As exosomes are virus-sized membranous particles and share viruses in their biophysical characteristics, this technique is often used in scientific research to separate and purify exosomes. This method usually uses polyethylene glycol (PEG) to reduce the exosomes solubility and precipitate them followed by centrifugation. Rider et al. [145] recommended the modified polymer coprecipitation (ExtraPEG) method for exosome separation and reported that this technique is cost-effective and outperforms the ultracentrifugation technique in terms of recovery and purity depending on comparative study between three technologies of commercially available commercial kits, ultracentrifugation, and modified polymer co-precipitation (ExtraPEG). This method has the advantage of processing large doses of samples and is relatively easy to operate with a short analysis time. Although, false positives may be obtained within this method and eradicating the produced polymer is hard.

\subsection{Size-Based Isolation Techniques}

Size exclusion chromatography (SEC) is a technique applied in exosomes separation from other components in biological samples depending on their size difference as the macromolecules cannot pass in gel pores and subsequently eluted, whereas the small molecules trapped in the gel pores which finally eluted with the mobile phase. The advantages of this technique are easy, cheaper, fast and the isolated exosomes are uniform in size, and their biological features are not significantly damaged. The disadvantage of this method is low purity as other components have a similar size [142]. Recently, Exo-spin exosome purification columns, EV Second purification columns, and EV separation columns are commercially available. In addition, the ultrafiltration technique using membranes with diverse molecular weight cutoffs is used for exosomes separation and also faced the problem of low purity [146].

\subsection{Immunoaffinity Chromatography (IAC)}

Immunoaffinity chromatography is another technique used for exosomes separation and purification depending on the affinity or binding of ligands and antibodies to separate them from a biological fluid. The efficiency of this method is mainly attributed to the affinity of desirable components and ligands, matrix carriers, and elution conditions. In addition, the targeted biomarkers used for exosomes separation and purification by this method should be high-abundance on their surface, for example, ESCRT complex-related protein and four-transmembrane protein superfamily. The advantages of the IAC technique are high purity, high sensitivity, strong specificity, use for quantitative and qualitative determination of exosomes, and the starting sample volume not being limited when magnetic beads are used $[147,148]$. In addition, the quantitative analysis showed that the exosomes 
yield obtained from this method is equal to that of ultracentrifugation, but the applied sample is much smaller as the RNA amount extracted from $400 \mu \mathrm{L}$ plasma using IAC is equaled the amount obtained from $2.5 \mathrm{~mL}$ sample using ultracentrifugation technique [149]. In contrast, this method faced different problems that limited its propagation as exosomes extracted by the IAC technique required harsh storage conditions, were contaminated with interfering proteins, and were not an effective technique for large-scale purification. Recently, commercially available kites have been developed based on the above-discussed method and scientists exerted their efforts to overcome the problems faced by exosomes purification, for example, development of a new micro-vortex chip technique, that is integrated with modified nanoprobe Morpho Menelaus butterfly wings [148]. Although several techniques have been developed for exosomes purification, they cannot meet all requirements and the combination between these techniques is the best. The exosome characterization process required developed and optimized guidelines to determine whether the extracted elements are exosomes. International Society for Extracellular Vesicles (ISEV) recommended [26] two main principles for the identification of extracted exosomes, the first point is the determination of two types of proteins (like cytosolic proteins recovered in EVs and transmembrane or GPI-anchored proteins associated to plasma membrane and / or endosomes) and the second point is the assessment for exosomes purity and they are free from associated non-EV structural protein components during extraction from biological fluids. Exosome characterization approaches are generally divided into two types: inclusion characterization (such as lipid raft and membrane protein) and external characterization (morphology and particle size determination). Several investigations depended on three levels for characterization of isolated exosomes, including determination of exosome morphology using a Transmission electron microscope (TEM), determination of exosome surface protein markers through Western Blot analysis, and identification of exosome size through Nanoparticle Tracking Analysis Technology (NTA) [150,151].

\section{Exosomal Pathway and Viral Pathogenesis}

There are over one hundred million people worldwide who are affected by microbial (bacteria, fungi, viruses, parasites) diseases such as tuberculosis, acquired immune deficiency syndrome, and malaria [152]. Throughout recent decades, information about exosomes has progressed in a diversity of scientific directions, predominantly regarding viral infections. Exosomes were found to be either inhibited or to promote the process of viral infection and pathogenicity depending on the pathogen and its target. In all circumstances, exosomes can make possible communications between pathogens and host cells or between host cells [153]. Recently, several studies have recognized exosomes and their crucial role in viral pathogenesis and immunity [121]. Exosomes transfer antiviral elements and activating antiviral mechanisms in a variety of cells allowing the host to mount effective immune responses against different viruses [123]. Exosomes enclosing viral genomes can transfer them to susceptible cells aiding viral spread and evading immunity infiltration [76]. In certain circumstances, exosomes that comprise viral proteins or nucleic acids stimulate immune responses in myeloid cells [114]. Several studies on Human Immunodeficiency Virus type-1 (HIV-1), human T-cell lymphotropic virus (HTLV), Dengue Virus, and Hepatitis $\mathrm{C}$ Virus (HCV) have shown that exosomes shed from virus-infected cells are loaded with various regulatory factors, including cellular and viral proteins, miRNA assisting in regulating cellular responses, and producing infections in neighboring cells [121].

\subsection{Viruses Hijack the Exosomal Machinery System (ESCRT and Rab GTPases)}

Viruses are intracellular obligate parasites exploiting cellular replicating machines to produce new progeny. Recent studies have shown that some viruses can hijack vesicular trafficking machinery for their transmission, assembly, and egress [17,121]. HIV-1 and HIV-2 exhibit similar structural and molecular features with exosomes. They are enclosed by a lipid bilayer containing RNA species [154], proteins [22,155], lipids [156], and carbohydrates [157]. In addition, the density and size of both range from 1.13 to $1.21 \mathrm{~g} / \mathrm{mL}$ [79] and 
50 to $150 \mathrm{~nm}$ in diameter [61], respectively. Depending on these similarities, different studies have reported identical pathways of HIV-1 production and exosome biogenesis [39,154]. In approval of the Trojan exosome hypothesis, HIV-1 exploits the host ESCRT complexes for viral budding $[15,123]$. The association between HIV-1 Gag protein and tetraspanin suggests that HIV-1 assembly may involve lipid raft domains rich in tetraspanins [158]. In addition, HIV-1 Gag has been shown to interact with CD63 and CD81 located on the surface of some exosomes aiding in virion egress [78]. Human herpesvirus 6 (HHV-6) infections intensely increase MVB formation for virions survival and also egress together with exosomes exploiting the same pathway [124]. Moreover, HHV-6 glycoprotein gB was found in association with CD63, impressing the importance of the endosomal pathway for HHV-6 infection and assembly [124], but the account of this association for virus egress has not been proven. Over hijacking the ESCRT pathway, certain viruses can also exploit the Rab GTPase complexes for viral egress and complete their replication processes. Many negative-strand RNA viruses, like respiratory syncytial virus (RSV), Hantavirus, and influenza A virus (IAV), all have been exploiting the Rab pathway for transport through the plasma membrane [159-162]. In addition, interfering with Rab11 protein levels can promote or inhibit the release of exosome-carrying different compounds: anthrax toxin, transferrin, flotillin, and HSP-70 [159,163,164]. Hantavirus and influenza A virus (IAV) also appear to recruit the Rab11 pathway to their profit $[160,162]$ while its depletion leads to a tenfold reduction in hantavirus production [161]. Another member of the Rab GTPase family, Rab27a, has been reported to be necessary for exosome biogenesis, mainly during the MVBs fusion with plasma membrane for exosome releasing $[165,166]$. The levels of Rab27a have increased with cytomegalovirus (CMV) infection and colocalize at assembly sites with the viral envelope components [167], but the changes and molecular mechanisms of the exosome production are not completely understood. In addition, HIV-1 proteins are found to interact with Rab27a, increasing exosome formation levels $[168,169]$. Herpes simplex virus 1 (HSV-1) appears to recruit Rab27a on intracellular transport and exocytosis steps as downregulation or depletion of Rab27a results in the reduction of HSV-1 production $[170,171]$. Although the concept of interaction between cells and stimuli to regulate the distribution, secretion, degradation, recycling, and the level of intracellular proteins is widely believed, Rab GTPase regulatory functions are still not completely understood [172]

\subsection{Signatures of Different Viruses in Exosomes and Their Role as Vehicles for Viral Elements}

The common features between the cellular endosomal/exosomal pathway and different viruses' life cycles besides exploiting the exosomal pathway for virus profit encouraged several studies to identify viral signatures in exosomes not only in terms of viral diagnosis but also for demonstrating the mechanisms of viral pathogenicity. We now have a growing list of viral-specific components that have been identified in exosomes (Table 1). Moreover, functional analysis of excreted exosomes carrying viral components is beginning to shed light on how some viruses can modulate cellular processes as diverse as immune evasion, apoptosis, proliferation, and even viral infectivity (Figure 2). Among viruses family, human herpesviruses have received extensive studies, especially Kaposi's sarcoma virus (KSV) and Epstein-Barr virus (EBV) that are oncogenic and associated with the development of several human malignancies [173]. Commonly, these viruses have been reported to recruit the exosome pathway to excrete several components ranging from different RNA species, including microRNAs (miRNA), messenger RNAs (mRNA), and small non-protein-coding RNAs to proteins [120,174-176]. In the case of EBV-infected cells, the released exosomes comprised an intense amount of viral miRNAs which identified for the first time, seem to be the smaller products of larger BamH1 EBV transcripts and work in association with cellular miRNAs to modulate target genes expression in recipient host cells [175,177-180]. Moreover, exosomes not only constitute as carriers of virus RNA species but also for viral-specific proteins as the exosomes shed from EBV- infected cells contain non-protein-coding EBV small RNAs (EBER-1/2) [91], viral envelop glycoprotein 350, and the latent membrane protein 1 and 2A (LMP-1, LMP-2A) [88-90,181]. The highly 
abundant EBV RNA polymerase II/III transcripts, EBER1/2, are expressed during the latency stage in all EBV infected cells. Although, the reason for their abundance in infected cells, or their excretion within exosomes, is still intriguing; one study indicated that they could activate Toll-like receptor 3 enhancing innate immune responses [182]. HIV-1, which belongs to the retroviruses family and is responsible for AIDS syndrome, is another virus receiving great attention. Retroviruses are slightly larger than exosomes; therefore, mature infectious HIV-1 particles cannot secrete within exosomes but are released together in the same fraction suggesting HIV-1 egress is partially mediated by the endosomal pathway [183]. Furthermore, exosomes derived from HIV-1-infected cells have been shown to incorporate different HIV-1 RNA species, including vmiR88, vmiR99, vmiR-TAR transcripts [80], and two HIV-1 proteins; Gag [184] and Nef proteins [185,186]. It has been reported that, among viral microRNA species, vmiR99 and vmiR88 stimulate macrophages signals (Toll-like receptor-8 (TLR8)), rising TNF $\alpha$ level [187] while vmiR-TAR transcripts have been suggested to augment HIV-1 replication through downregulation of apoptotic pathway in the recipient host cells [188]. HIV-1 Nef protein is interacted with exosomes upon anchoring into lipid rafts through its $\mathrm{N}$-terminal myristoylation and basic amino acid residues of its alpha-helix-1 [189]. Lately, several studies have shown the crucial role of Nef protein in viral replication and infection through the transformation of resting bystander CD4+ T cells to HIV-1 susceptible cells $[111,186,190]$ while HIV-1 Gag protein plays a role in HIV-1 assembly and egress through the interaction with the exosomal membrane tetraspanins, CD81 and CD63 [110,158,191,192]. In addition, exosomes incorporating viral co-receptors, CXCR4, and CCR5 may aid in HIV-1 spread and infection by secreting to other cells $[193,194]$. In the same way, human T-lymphotropic virus 1 (HTLV-1) appears to recruit the exosomal system as a vehicle to transport its active components including viral mRNA transcripts and functional proteins. A recent study revealed that the HBZ, Env, and Tax gene mRNA transcripts and trans-activator protein, Tax, released within the exosomes shed from HTLV-1-infected cells [118,195]. In the case of human T-lymphotropic virus 1 (HTLV-1)-associated myelopathy/tropical spastic paraparesis (HAM/TSP), analysis of the exosomes isolated from patient cerebrospinal fluid showed the presence of transactivator protein Tax, proposing that HTLV-1 may release specific cargo for modulating its microenvironment [196].

Recently several studies have supported the idea that exosomes act as an alternative tool for HCV transmission and infection. HCV-infected hepatocytes excreted exosomes within the complete $\mathrm{HCV}$ genome and able to transfer HCV subgenomic replicons RNA to recipient cells resulting in viral replication and infection [52,92]. Exosomes can successfully deliver HCV RNA to dendritic cells to establish viral infection [94] and stimulate IFN- $\alpha$ production [165]. Furthermore, Bukong et al. [93] reported that exosomes shed from HCVinfected patients have been comprised of negative-sense HCV RNA complex with miR-122, Ago2, and HSP90 [93]. Similarly, the human Pegivirus that was earlier known as the Hepatitis $G$ virus recruits exosomes as a means to transport viral RNA to peripheral blood mononuclear cells and establish a productive infection [197]. In addition, exosomes derived from Ebola virus (EBOV) infected cells enhanced EBOV infectivity. These exosomes were loaded with cytokines contributing to EBOV pathology and EBOV matrix protein, VP40 which act on recipient cells leading to decrease monocytes and $t$ cells viability $[141,142]$. As the number of exosomal components that is originated from cells and microbes is continually increasing, several online databases are launched to catalog exosome contents. Furthermore, recent studies are beginning to explore the cargo of exosomes derived from virally infected cells and their role in the pathogenesis of viral infections. The mechanism through which cellular and microbial components are selected to be packaged into exosomes and the possibility of using exosomes as biomarkers for many disease progression and different viral infections is the main challenge to be understood [198]. 


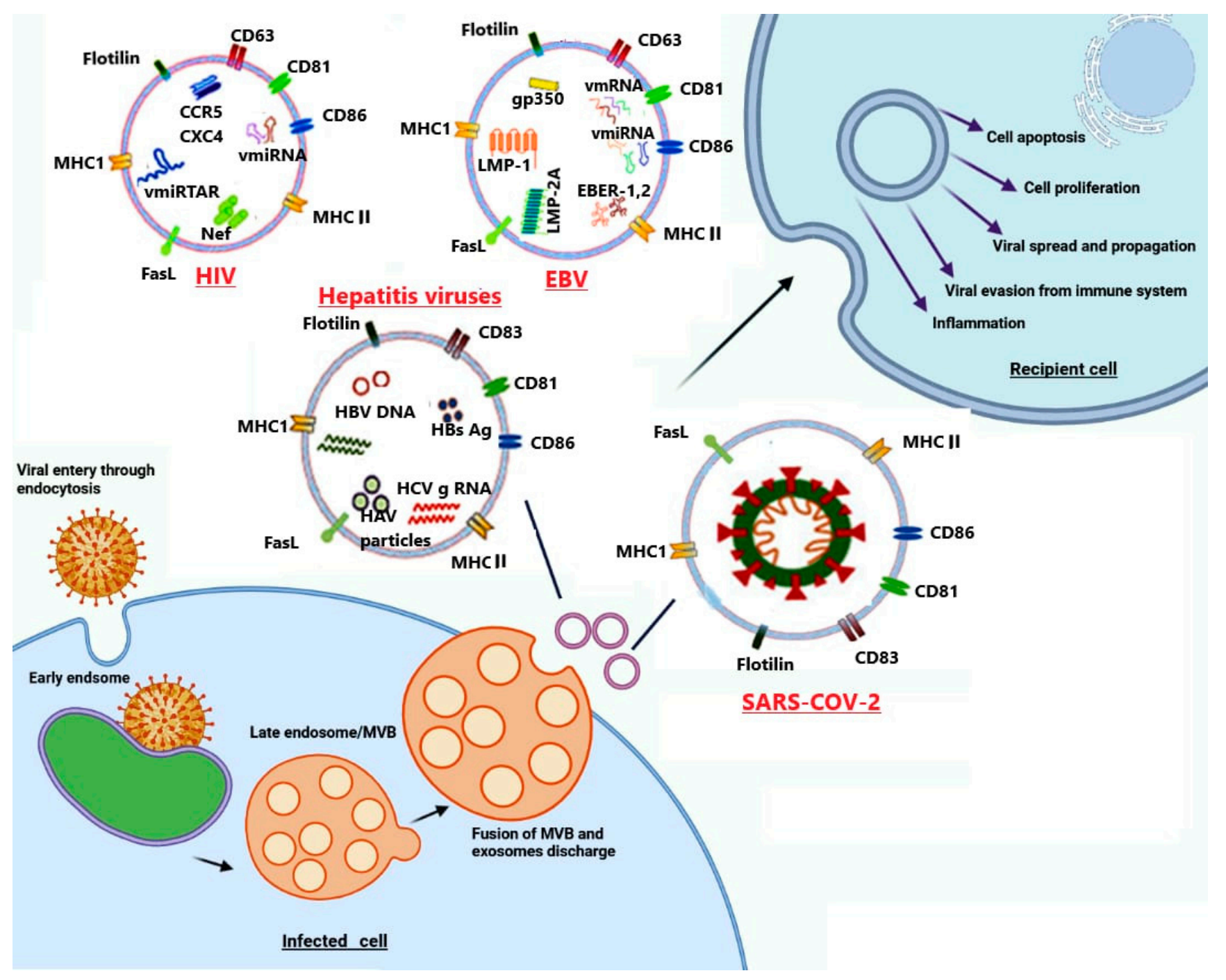

Figure 2. Schematic representation displayed many different viruses hijacking the cellular endocytosis and recruiting exosome as potential mediator in their infection, propagation, and pathogenesis. Here four examples are displayed; HIV, hepatitis viruses, and EBV can export their RNAs and proteins within exosomes. In addition, SARS-CoV-2 can recruit endosomal pathway to export intact virus, their genetic material, or proteins within exosomes.

\subsection{Role of Exosomes as Potential Mediators in Viral Pathogenesis}

Exosomes derived from viral-infected cells export viral components together within the cellular one [80,198]. Besides, viruses excrete their elements in exosomes; they somehow control which cellular products are transported within the exosomes as the cellular component packed within the exosomes is different within the same non-infected cells $[91,120,176]$. Consequently, the viral components of the exosomal cargo are responsible for any pathophysiological effect on recipient cells. Although several data display that exosomes shed from viral-infected cells induce different processes including, cytokine modulation, immune evasion, transcellular spread, apoptosis, and proliferation, the exact molecular mechanisms through which these processes occur are not understood [11,34]. In the case of EBV, exosomes shed from EBV-infected B cells attack epithelial cells through caveolar-dependent endocytosis and their cargo induce physiological changes [199]. It has been reported that exosomes from EBV-immortalized lymphoblastoid cell lines (LCLs) and nasopharyngeal carcinoma (NPC) promote apoptosis or inhibit EBV-reactive CD4+ cells proliferation [90,200,201]; also, similar observations were reported with exosomes from NPC-xenografted mice and EBV-associated from nasopharyngeal carcinoma cases [202]. 
The cargo of these exosomes comprises viral and cellular elements as viral miRNAs, latent membrane protein-1 (LMP-1), LMP-2A, and cellular galectin $9[18,89,202]$. The EBV-LMP-1 is an oncoprotein that has a role in the immortalization of EBV-infected B lymphocytes [203]. LMP-1 of EBV-infected cells is functionally homolog of TNF receptors as it activates nuclear factor $\mathrm{KB}$ (the main transcription factor) through transmitting growth signals from cell membrane to the nucleus in TNF-receptor associated factor pathway [204,205]. In addition, the other EBV latent membrane protein, LMP-2A [206], plays a crucial role in EBV pathogenesis and latency or mediates EBV-infected B cells immortalization as it mimics a constitutively active B-cell receptor (BCR) activator even in the absence of BCR signaling $[207,208]$. Despite the secretion of EBV-latent membrane proteins within exosomes enhancing EBV pathogenesis in the recipient cells, the function of these proteins in the recipient cells and how they are selected to be excreted within exosomes is still one of the major challenges to be understood $[90,200]$. Lately, it has been reported that exosomes derived from EBV-infected B cells export Fas-ligand (Fas-L) to recipient cells where they induce apoptosis in a dose-dependent manner via an extrinsic pathway, and anti-Fas-L antibodies could block this process [87]. In addition, another study showed that Fas-L and MHCII molecules excreted within the exosomes derived from lymphoblastoid cell lines, prompting apoptosis in CD4+ T cells [201]. From these studies, the shedding of exosomes within signals which promote apoptosis and/or inhibit anti-EBV-infiltrating lymphocytes is a strategy through which EBV could evade the immune system.

Some viruses can exploit a mechanism of downregulating their lytic gene expression to escape the immune responses and establish latency in the infected cells [209] as the immune system is not triggered unless viral antigens are expressed [210]. Herpes simplex virus type 1 (HSV-1) is one of the Alphaherpesvirinae family primary replicating in mucosal epithelial cells and established their latency in sensory ganglia [211]. In the latency, abundant vmiRNAs have been identified without viral protein expression, and some of these vmiRNAs have a significant role in latency establishment through the suppressing of viral gene expression [212-214]. Recent studies have revealed that HSV-1 can spread its infection through exporting significant components within exosomes to the recipient cells such as vmiRNAs important for suppression of viral gene [215] while HSV-1 can suppress cell-cell transmission through excretion of antiviral factor, STING within exosomes to recipient cells in unfavorable conditions [83]. These strategies enable HSV-1 to persist and escape from immune eradication. In addition, L-particles are subviral non-infectious particles (not viral DNA or viral capsid) released from HSV-1-infected cells within exosomes to recipient cells [216,217] suggesting their role in facilitating viral infection and immunity infiltration via microenvironment modulation [218]. Similarly, some viruses transport molecules that neutralize antiviral and cellular host inflammatory factors within exosomes modulating their microenvironment $[42,219]$. In hepatitis B virus (HBV) infection, the serum was found to comprise subviral non-infectious elements at the level of 1000 times higher than mature infectious virus, which raises the question about the selectivity of HBV to secrete such non-infectious particles $[113,220]$. One of the most acceptable suggestions is that these non-infection particles act as a trap and switch the immune response to recognize infectious virions [14,113]. Furthermore, some members of the herpesviridae family, including herpes simplex virus type-1, human herpesvirus 6 (HHV-6), and cytomegalovirus (CMV) can recruit the endocytic pathway to complete their assembly and egress steps during their replication [80]. In HSV-1 infection, the interaction of enveloped glycoproteins (gD and $\mathrm{gH}$ ) and tegument protein with Rab27a resulted in depletion of Rab27a and thus reducing viral egress and production and signifying Rab27a role in HSV-1 production [171].

The role of exosomes in HIV-1 infection is not completely known; several studies reported that exosomes can either inhibit or enhance HIV-1 infectivity and pathogenicity. Recent studies have shown the significant role of exosomes in HIV-1 infection. HIV-1 coreceptors CCR5 and CXCR4 have been reported to be transferred within exosomes from HIV-infected cells to uninfected, non-permissive cells, making them more susceptible to viral infection $[193,194]$. Recently, it has been reported that exosomes excreted from 
monocyte-derived macrophages enclosed a portion of HIV-1 virions and the infectivity of these enclosed virions toward CD4+ target cells is better than the HIV-1 virus particles [221]. The plasma cytokines levels are relatively increased in HIV-1 infection and several cytokines have been reported to be excreted within exosomes, playing a significant role in viral propagation and inflammation. The infection of peripheral blood mononuclear cells with exosomes purified from HIV-1 positive individuals resulted in stimulating CD38 expression on central memory CD8+ and CD4+T cells, which activated bystander cells and facilitated viral transmission and inflammation [222]. Recently it has been reported that exosomes excreted from HIV-infected cells containing molecules of MHC Class II, CD86, and CD45 may help in silencing immune response, thus supporting HIV replication [223], while exosomes released from HIV-1 infected CD8+ T cells inhibited transcription of CXCR4 and CCR5-tropic HIV-1 strains in the chronic and acute infection models [224]. As well, HIV-1 accessory protein, Nef is also excreted within exosomes and has a significant role in HIV-1 infection via assisting in CD4+ T cell depletion that is the target infection of HIV-1 [185]. Nef interacts with the cytosolic tail (CT) of MHC-I and CD4 resulting in the interruption of the intracellular trafficking process and making these proteins a target to multivesicular bodies and finally degradation by lysosomes. HIV-1 Nef exported within the exosomes modulates exosomal miRNA composition [186] and prompts the activation of quiescent CD4+ T lymphocytes to be permissive to HIV-1 infection and transmission [190]. Recently, in vitro study reported that exosomes shed from CD4+ T cells not from CD4T cells well inhibit HIV-1 infection, proposing that exosomal CD4 interacts with HIV-1 envelope proteins, neutralizing HIV-1 and preventing its interaction with target cells [186]. This study also reported that this neutralization activity can be reversed through depleting CD4 exosomes excreting from Nef expressed CD4+ T cells [186]. Moreover, cellular defense enzyme, human cytidine deaminase APOBEC 3G (A3G) has been reported to be exported within exosomes and gained recipient cell resistance against defective and wild-type HIV-1 infection [225]. As mentioned above, HTLV-1 recruits exosomes for transporting functional viral elements (HTLV-1 mRNA transcripts of HBZ, Tax, and Env proteins, proinflammatory mediators, and HTLV-1 Tax protein) together with cellular host protein (major histocompatibility complex class I A and E). The exposure of myeloid dendritic cells to exosomes enclosed Tax protein and derived from C81 cells resulted in significant elevation of cytokines level, including IL-6, IL-5, and IL-2 while, cell-free Tax stimulates the cytokines secretion of G-CSF, IFN, IL-17A, IL-12, and IL-10 from dendritic cells suggesting the exosomal trafficking role in HTLV-1 infection [118].

In HCV infection, exosomes not only act as a vehicle for HCV transmission to naive cells but also a place where virions escape from antibody neutralization. A recent study using transmission electron microscopy showed that $\mathrm{HCV}$ was existing in exosome-associated and exosome-free forms and exporting within exosomes has the advantage of protection against HCV antibody-mediated neutralization, making the transmission within exosome a significant mechanism by which HCV can escape from the immune system [92], [226]. Similarly, Hepatitis A virus (HAV) was found to be enclosed within membranous vesicles derivative from endosomal membranes and still infectious. These encapsulated HAV particles used the ESCRT pathway for their biogenesis which confers a protective mechanism against different neutralizing antibodies [172]. The level of an antiviral protein called interferon-inducible transmembrane proteins 3 (IFITM3) in the host cell is reversely related to the host susceptibility to infection with dengue virus serotype -2 (DENV-2). Recently, it has been reported that exosomes excreted from HepG2 or HUVEC cell lines transport IFITM3 protein to bystander cells. In the recipient host cell, these IFITM3-containing exosomes effectively inhibited DENV-2 infection in a dose-dependent manner. This study reported a significant role for IFITM3-enclosing exosomes in DENV-2 infection through the reduction of DENV-2 penetration into host cells without any effects on the binding or post-entry steps [95].

Many viruses are reported to hijack host machinery of exosome biogenesis to regulate their production and virus secretion and used Trojan horse stratagem to enclose new viral 
progeny within exosomes helping viruses to spread and harbor from host defense [227]. SARS-CoV-2 is the newest positive-strand RNA virus that employs the cell membranous machinery to, through its nsp1-10, create a double-membrane vesicle (DMV) just a few seconds after it is attached to the ACE2 receptor, where the virus replicates, assembles, and finally exports into extracellular [228]. The main ideas that raise the question about the involvement of exosomes in SARS-CoV-2 infection are (1) pathophysiologies of SARS-CoV2 infection, mainly hyper activate immune response which promotes sepsis-like disease characterized by decreasing lymphocytic count and cytokine storm. (2) The exploitation of the TGN pathway (trans-Golgi network, which is a major secretory pathway sorting station in the endolysosomal pathway) through SARS-CoV-2 replication. (3) Recent studies reported that the pathogenesis of COVID-19 complications involved lipid metabolism as cholesterol metabolism $[229,230]$. Protein interactome analysis for SARS-CoV-2 displayed the interaction with Rab proteins (a part of the ESCRT pathway involved in exosome biogenesis) and strengthened the idea of involvement exosome in SARS-CoV-2 pathogenesis as many viruses interact with Rab proteins and hijack exosomes for pathogenesis $[167,171]$. Furthermore, high-throughput lipidomics of sera from infected people indicated that the lipid profile of derived exosomes enriched with gangliosides (GM3) and sphingomyelins and was deficient in Di-acyl glycerols (DAG). Gangliosides-enriched exosomes were likely the cause of lymphopenia as immune cells have a preference for such exosomes and these exosomes are strongly related to the disease severity [231,232]. Although Coronavirus disease 2019 (COVID-19), which was caused by the severe acute respiratory syndrome coronavirus 2 (SARS-CoV-2), is a newly born disease, it has reached a pandemic level with little information about its molecular targets, immunogenicity, and the role of epigenetics mechanisms as miRs and other noncoding RNAs in pathogenesis. Extensive studies suggest that these non-coding RNAs are packed within exosomes which shuttle them between different cell types, promoting sepsis and tissue injury. Recently, in vitro study helped us to predict the functional role of exosomes in the SARS-CoV-2 pathogenesis as it reported that transduction of SARS-CoV-2's structural and nonstructural genes with lung epithelial A549 cells results in the discharge of exosomes enriched with viral RNAs; taking the humaninduced pluripotent stem cell-derived cardiomyocytes (hiPSC-CMs) resulted in elevated inflammatory markers [233]. This result may interpret the possible mechanism of cardiac complications associated with SARS-COVID-19 infection that has mystified scientists. The SARS-CoV-2 infection resulted in the extensive inhibition and activation of protein kinases [234]; also, exosomes derived from virus-infected cells may be loaded with proteins that can stimulate the inflammatory system and cause different tissue injuries. One of the studies concerned with the development of a culture system permissive for SARS-CoV reported that human alveolar type II was susceptible to SARS-CoV infection and differentiation and SARS-CoV antigens were identified in the cytoplasm of infected cells. In addition, this study reported that electron micrograph detected virions in virus-induced secretory vesicles where the viral RNA increased with time indicating that SARS-CoV exploits it for their replication. The virions bud from the membranes of the ER-Golgi-intermediate is enclosed with secretory vesicles and released from cells by exocytosis [235]. As recently reviewed, the post-mortem histopathological analysis of samples taken from several organs of COVID-19-infected people revealed that the presence of SARS-CoV-2 particle and/or its proteome within the double-membrane vesicles (DMVs) of the host cells $[228,236]$. The electron microscopic examination of the renal tubular epithelium revealed the arrangement of coronavirus particles with their distinctive spikes in clusters [237]. Farkash et al. (2020) reported that an electron microscope examination for an autopsy renal sample from a COVID-19-infected patient showed an arrangement of viral particles in arrays indicating their intracellular manufactured and assembly. Furthermore, the presence of DMVs near the rough endoplasmic reticulum during viral assembly suggests that the assembly mechanism of the SARS-CoV- 2 viral is similar to that of SARS-CoV [238]. The outcome of these results recommended that the possible participation role of exosomal cellular transport in SARS-CoV-2 viral dissemination and serve as a valuable tool for the COVID-19 reactivation. 
However, the main infected organ of SARS-CoV-2 infection appears to be the lung, the detection of virion particles in urine [239], and stool [240] indicating their spread to other organs such as the kidney and intestine. Although SARS-CoV-2 is viremic, infection has been established in the blood; viral RNA is only rarely detected in blood [240]. SARS-CoV infected subpleural and peripheral alveoli and a type II cell is the site for its propagation, where the new progeny of viral particles is released, and the cells undergo apoptosis [241]. SARS-CoV- 2 and COVID-19 infection resulted in diffuse alveolar damage (DAD) with fibrin-rich hyaline and releasing of viral particles in free form or vacuolization with doublemembrane vesicles that targeting the neighboring new cells/tissues and circulating to reach distant tissues [242]. The virus can be spread reaching many organs and tissues, including the vasculature system $[243,244]$. Many cellular organelles bound with a lipid membrane that supports their structure and separates them from the cytosol also have an important role in different biochemical processes. To date, all reported positive-strand RNA viruses are characterized by promoting the formation of membranous vesicles, supporting their genomic replication in the cytoplasm $[245,246]$. In addition, the coronaviruses family stimulates double-membrane vesicles (DMVs) formation with an average diameter of $300 \mathrm{~nm}[245,246]$. These DMVs usually bud from the ER-Golgi intermediate compartment or the endoplasmic reticulum (ER) or ER-Golgi intermediate compartment and enclose the viral particles, newly replicating viral genome, and viral replicase proteins. DMVs diversity may interpret the elapsed cases of reinfected (for your knowledge, we are the first to propose this idea) patients as some of them are asymptomatic with PCR positive and the other exhibited acute to mild COVID-19 symptoms [236,247]. The involvement of such membranous vesicles considers one of the viral strategies to readjust and redirect host cell membranes to participate in viral replication and transcription processes [246,248-250]. However, we have discussed the role of exosomes in viral pathogenesis and infection and how several viruses recruit them for their benefit; it should be taken into consideration that exosomes excretion is a normal physiological process and also exhibits a crucial role in protecting host cell against pathogens $[11,251]$. Recently, it has been reported that isolated exosomes from healthy persons' semen could inhibit HIV-1 replication in vitro (Madison and Okeoma 2015b) without any effect on HSV-2 or HSV-1 replication [39]. Unfortunately, certain viruses can control these defense mechanisms and recruit them to their profit.

\section{Exosomes as a Potent Therapy in Viral Infections}

As discussed above, exosomal vesicles constitute a tool of communication between different pathogens and their hosts. Recently, exosomes are considered an attractive area to develop a new drug and can be used as vaccines, drug delivery vehicles, and a diagnostic marker (Figure 3). The possibility to be used as a biomarker for different diseases is attributed to their cargo that differs in diseased and normal conditions and has been identified in all body fluids. Intensive studies are required to explore potential applications of exosomes as diagnostic and prognostic tools in viral infection. Targeted delivery is an area that received great attention as exosomes can be loaded with therapeutic drugs and carry them to specific tissues or organs. In addition, genetically engineered exosomes that are modified to express receptor-specific ligand molecules on their surface are considered a novel system to carry a drug/ miRNA/siRNA-based therapeutic molecule to specific organs. In addition, the incorporation of virus-encoded envelope proteins within genetic material or therapeutic biomolecule into exosomes displaying their superior binding and entry specificity and enhancing their delivery is new [252]. Several studies reported that exosomes can be engineered to express a 29-mer peptide that is generated from the rabies virus glycoprotein (RVG) and specifically binds to acetylcholine receptors on the neurological cell surface. Alvarez-Erviti and coworkers were the first to exploit the RNA-transporting capacity of modified exosomes for transporting small interfering RNAs (siRNA) across the blood-brain barrier. Their study aimed to develop nonimmunogenic targeted delivery of the potential RNA drugs. Targeting was done by transfecting immature dendritic cells (DCs) with plasmids encoding exosomal protein lysosome-associated membrane glyco- 
protein $2 b$ (Lamp2b), fused with the brain-specific RVG peptide. Purified exosomes were loaded with GAPDH or BACE-1 siRNA and intravenously injected in wild-type mice through the tail. The targeted exosomes specifically delivered GAPDH or BACE-1 siRNA to the mouse brain resulted in a specific knockdown of GAPDH and BACE-1 genes [253]. In addition, engineered exosomes purified from DCs that transduced with adenoviral vector to express FasL, Interleukin (IL)-10, or IL-4 were applied in inflammatory diseases and autoimmune disorders' treatment [254]. Exosomes are evaluated as cell-free vaccines in infectious diseases. Aline et al. (2004) demonstrated the efficacy of exosomes shed from the DC2.4 cell line as a novel cell-free vaccine inducing protective immunity against toxoplasmosis [255]. Their investigation revealed that exosomes derived from a DC2.4 cell line that had been pulsed ex vivo with Toxoplasma gondii are transferred rapidly and preferentially from the intestine, cervical lymph nodes to the spleen and triggered systemic Th1-modulated Toxoplasma-specific immune response in vivo [255]. In addition to their ability to develop protective immunity against Toxoplasma infection, they can be applied as immunoprophylaxis against several viral infections. Exosomes received increasing attention as potential therapeutic modalities (Figure 3); due to their biocompatibility, they offer many advantages, including a means of communication between cells, ability to interact with antigen-presenting cells, representing a good and stable environment for proteins and nucleic acids by protecting them from proteinases, DNase, and RNase, and offering a better distribution tool as they are detected in all bodily fluids $[252,256]$.

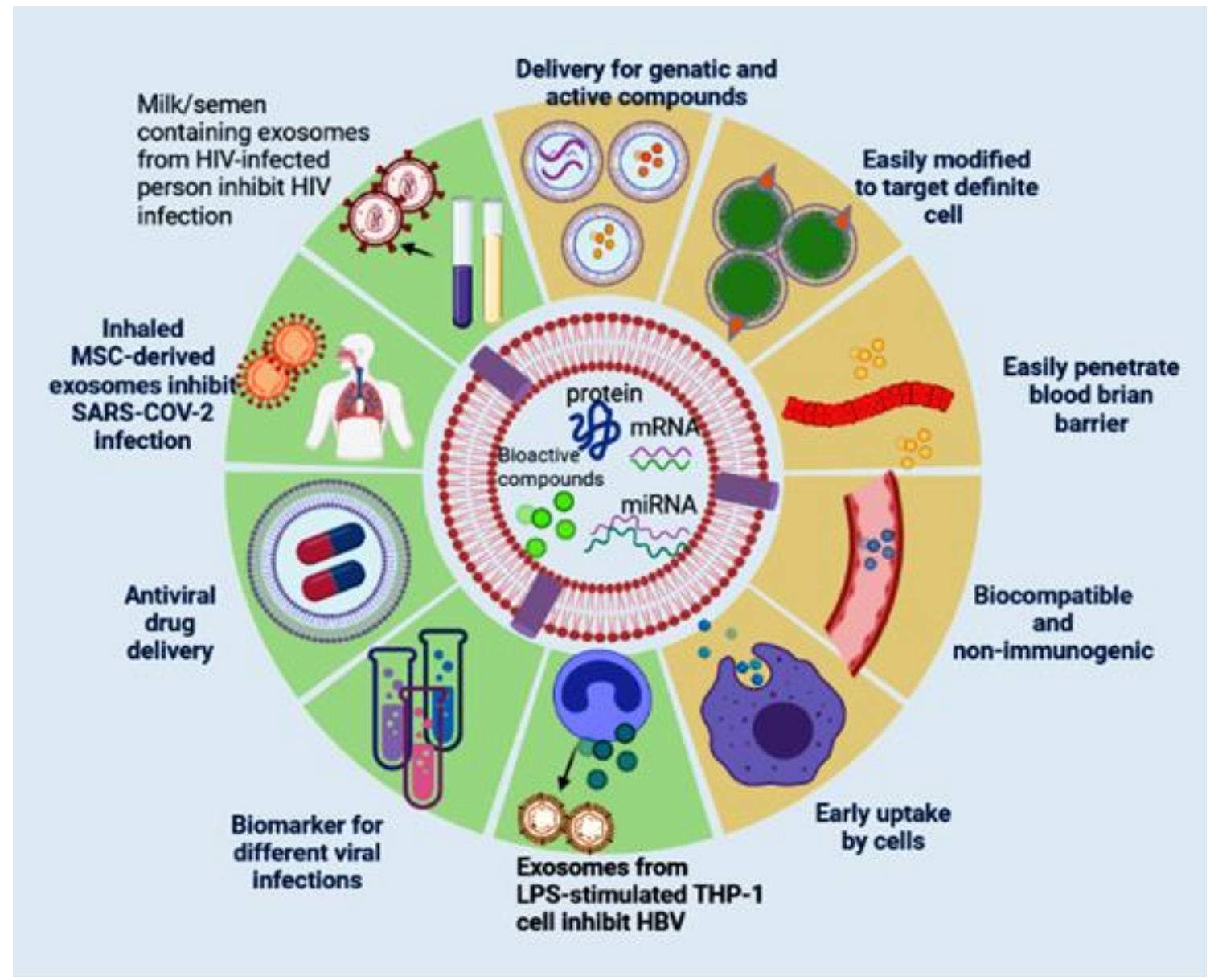

Figure 3. Schematic representation showed the potential exosomal features and their application in different viral treatments. A; display exosomal advantages including delivery for genetic materials, proteins, and drugs, easily modified to target definite cells, biocompatible and non-immunogenic, easily penetrate blood-brain barrier, and easy uptake by cells. B; display their application in different viral treatments such as, HBV, HIV, and SARS-COV-2 (Table 2). 
It has been reported that exosomes driven from a human monocytic cell line (THP-1) that had been stimulated with lipopolysaccharide endotoxin (LPS) can trigger cytokines such as interleukin 1 beta (IL-1 $\beta$ ), tumor necrosis factor-alpha (TNF- $\alpha$ ), ligand 5 (CCL5), and chemokine (C-C motif), modulating inflammatory response in healthy mice. In addition, these exosomes were exploited as hepatitis $\mathrm{B}$ recombinant antigen adjuvants, as they hastened the appearance of IgG antibody production and enhanced IFN- $\gamma$ concentration [257]. While these results displayed the capability of the unmodified exosomes to be used as coadjuvants triggering immunostimulatory effect, engineered exosomes can be used as targeted drug delivery, transporting specific molecules for treating different diseases in vivo. Ferrantelli et al. (2018) reported that the product of the fusion between viral antigen and exosome anchoring protein Nef mutant (Nef ${ }^{\text {mut }}$ ) can be expressed in DNA vector and the strong ability of Nef mut to accumulate in multivesicular bodies leads

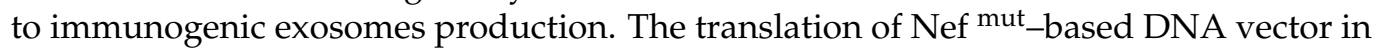
animal results in engineered exosomes which enclose a huge amount of viral antigen and induce cytotoxic $\mathrm{T}$ lymphocyte (CTL) immunization against viral infection. In addition, Ferrantelli et al. [258] reported that the product of the fusion between HBV core protein and exosome anchoring protein $\mathrm{Nef}{ }^{\text {mut }}$ can express in DNA vector generated exosomes which encloses huge amounts of $\mathrm{HBV}$ core protein and induces cytotoxic T lymphocyte (CTL) immunization against HBV. The advantage of exosomal delivery of specific antiviral molecules makes them a potential therapeutic strategy and/or non-promising vaccine for HBV [258].

In the field of HIV-1, the detection of HIV-1 RNAs and proteins in exosomes derived from the blood of seropositive patients highlights the potential value of exosomes and their cargo as biomarkers for HIV-1. The packaging of HIV-1 components within exosomes derived from the blood of HIV-1-seropositive patients suggests that the body gets rid of viral elements by secreting them into exosomes. The potential of these exosomes as prognostic and diagnostic HIV-1 biomarkers by inducing the shedding of exosomes enclosing the HIV1 genome to clear the body of viral element and efficient degradation of viral genome can be achieved by engineered exosomes. Recent studies reported that human semen $[39,123]$ and human breast milk-derived exosomes [259] control HIV-1 infection in cell culture thus biofluid exosomes or biofluid exosome-based synthetic nanoparticle delivery systems that enclosing anti-HIV-1 effectors can be applied as potent therapy for AIDS. Moreover, the replication of the murine acquired immunodeficiency syndrome (mAIDS) virus inhibited in the mouse vagina when exposed to human semen-derived exosomes simultaneously with the virus [123]; similar inhibition can occur during sexual transmission when human vaginal mucosa is exposed to HIV-1-seropositive semen. In addition, mice that received the exosome/virus complex showed a reduction in plasma viremia and decreased systemic virus dissemination. These results mark the potential therapeutic effect of semen-derived exosomes on systemic virus spreading and mucosal HIV-1 transmission [123]. The protective properties of milk and semen-derived exosomes against horizontal (sexual) and vertical (milk-borne) HIV-1 transmission made them promising therapeutics for AIDS.

Although the number of clinical investigations to find therapeutic solutions for COVID19 is growing, no specific vaccine or antiviral treatment is available. Some studies reported that mesenchymal stem cells (MSCs) and/or EVs shed from them can be applied to treat COVID-19 patients owing to their immunomodulatory effect. MSCs or EVs derived from secret different types of cytokines and paracrine factors that suppress the immune system over activation through directly interact with immune cells, including natural killer cells, macrophages, B cells, T cells, and dendritic cells. Furthermore, they secrete and attract different growth factors such as VEGF, TGF, and EGF which improve the microenvironment and promote regeneration of tissue [260]. However, the disadvantages of using MSCs have been reported; for example, the intravenous administration may result in embolus formation, and MSCs derived from embryonic tissue may increase the risk of tumorigenicity and mutagenicity, so the products of MSCs like exosomes [261] and secretome [262] have been recommended as an alternative therapy. Previous studies recommend EVs derived 
from the cell secretome in the treatment of COVID-19 [263]. In addition, EVs isolated from MSC were reported to produce promising effects as their parental cells with advantages of producing similar or better results than MSCs in vivo investigation, and they are still functional after storing for long periods [261]. By the end of 2020, seven registered clinical trials were using EVs as a strategy to overcome COVID-19 infection [264], and Table 2 displays current clinical trials that apply exosomes in the treatment of COVID-19 infection. Clinical trial NCT04276987 was built to estimate the safety and efficiency of aerosol inhalation of the exosomes isolated from allogeneic adipose MSCs in the treatment of hospitalized COVID-19 patients suffering from coronavirus pneumonia [265] with a protocol assigned to give participated patients conventional treatment and one dose of aerosol inhalation of MSC-derived exosomes $\left(2 \times 10^{8}\right.$ nanovesicles $\left./ 3 \mathrm{~mL}\right)$ for five uninterrupted days. In the treatment of COVID-19 pneumonia, another clinical trial (ChiCTR2000030261) suggested direct delivery of MSC-derived exosomes into the lungs through the atomization process and the reduction of inflammatory factors and immunity response will be assessed [266]. The clinical trial ChiCTR2000030484 suggested the use of human umbilical mesenchymal stem cells (HUMSCs) and their derived exosomes for the treatment of lung damage in COVID-19 patients [266]. Furthermore, one published study aimed to explore the safety and efficacy of bone marrow MSC-derived exosomes in the treatment of COVID-19 infected patients [267]. After four days of treatment, the laboratory tests and clinical symptoms for these patients were improved without observed adverse effects. The increase in lymphocyte count, the decrease in acute phase markers such as ferritin and C-reactive protein, and the normalization of the neutrophil count were reported.

Table 2. Current clinical trials that apply exosomes in the treatment of COVID-19 infection.

\begin{tabular}{|c|c|c|c|c|c|}
\hline Clinical Trials & $\begin{array}{l}\text { Applied } \\
\text { Therapy }\end{array}$ & Source & $\begin{array}{c}\text { Route of } \\
\text { Administration }\end{array}$ & Outcome/Aims & Ref \\
\hline ChiCTR2000030484 & MSCs and EVs & $\begin{array}{l}\text { MSCs derived from } \\
\text { the human umbilical } \\
\text { cord }\end{array}$ & Intravenous (IV) & $\begin{array}{l}\text { Exploring the safety and efficacy of } \\
\text { MSCs and EVs }\end{array}$ & [266] \\
\hline ChiCTR2000030261 & EVs & MSCs & Aerosol inhalation & $\begin{array}{l}\text { Promoting early recovery and } \\
\text { avoiding complications through } \\
\text { enhancing immunity and inhibiting } \\
\text { inflammatory factors }\end{array}$ & [268] \\
\hline NCT04389385 & EVs & $\begin{array}{l}\text { Allogeneic COVID-19 } \\
\text { specific T cells } \\
\text { (CSTC) }\end{array}$ & Aerosol inhalation & $\begin{array}{l}\text { Estimating the safety and efficiency } \\
\text { of inhaled CSTC-exosomes in the } \\
\text { treatment of early-stage pneumonia } \\
\text { resulting from COVID-19 infection. }\end{array}$ & [269] \\
\hline NCT04276987 & EVs & $\begin{array}{l}\text { MSCs derived from } \\
\text { allogeneic } \\
\text { adipose tissue }\end{array}$ & Aerosol inhalation & $\begin{array}{l}\text { Exploring the safety and efficiency } \\
\text { of inhaled EVs in the treatment of } \\
\text { COVID-19 infection. }\end{array}$ & [270] \\
\hline NCT04493242 & EVs (ExofloTM) & $\begin{array}{l}\text { MSCs derived from } \\
\text { allogeneic bone } \\
\text { marrow }\end{array}$ & IV & $\begin{array}{l}\text { Exploring the safety and efficacy of } \\
\text { EVs administrating intravenously } \\
\text { as a treatment for ARDS }\end{array}$ & [271] \\
\hline NCT04338347 & EVs (CAP-1002) & $\begin{array}{c}\text { Allogeneic } \\
\text { cardiosphere derived } \\
\text { cells }\end{array}$ & IV & $\begin{array}{l}\text { Evaluating the safety and efficacy of } \\
\text { EVs shed from allogeneic } \\
\text { cardiosphere derived cells in the } \\
\text { treatment of COVID-19 infection. }\end{array}$ & {$[272,273]$} \\
\hline NCT04491240 & EVs & MSCs & Aerosol inhalation & $\begin{array}{l}\text { Estimating the safety and efficiency } \\
\text { of exosome inhalation in the } \\
\text { treatment of COVID-19 pneumonia }\end{array}$ & {$[274]$} \\
\hline NCT04384445 & $\begin{array}{l}\text { HAF, containing } \\
\text { EVs } \\
\text { (OrganicellTM } \\
\text { Flow) }\end{array}$ & $\begin{array}{l}\text { Human amniotic } \\
\text { fluid } \\
\text { (HAF) }\end{array}$ & IV & $\begin{array}{l}\text { Exploring the safety of } \\
\text { HAF-derived acellular products and } \\
\text { their efficacy as a therapeutic agent } \\
\text { against COVID-19 infection. }\end{array}$ & [272] \\
\hline
\end{tabular}




\section{Conclusions and Future Perspectives}

Data in the present study represent a comprehensive overview of the role of the extracellular vesicles subtype, exosomes in the viral infection, and their pathogenesis mechanisms. Exosomes are a group of nano-extracellular double vesicles formed in the endosomal part of most eukaryotes. Exosomes serve as crucial regulators and mediators of the cell's communication via transferring their cargo to other cells, thus they have numerous biological purposes. The structure of exosomes is reliant on the tissue and cells' origin; consequently, they can be different in composition under varied pathological circumstances. Exosomes can be potentially hijacked by many viruses, thus making them influence many processes which are useful for use in many purposes. As a result, viruses utilize biogenesis systems of the hijacked exosome to activate their capsids packaging, regulate their production of virions, and the viral particles secretion. Furthermore, exosomes are being used as nano-carriers of the viral proteins and/or exogenous viral miRNA to be transferred to the non-infected cells. All of these make exosomes have potential importance in several biological functions such as cellular communication and immune modulation, as well as vehicles, to transfer many ingredients from one cell to another. In addition, SARS-CoV-2 is also using exosomes similar to other viruses to be transported for intra-host spreading and viral reproduction. Therefore, exosomes can be suitable candidates for the preparation and development of many viral vaccines for use in the treatment and prevention of many pandemic infections such as COVID-19.

Author Contributions: M.H.S.: Formal analysis, data curation, collected literature data, wrote, and edited the manuscript. R.B.: Formal analysis and evaluation, data curation, collected literature data. E.M.R.: Conceptualization, data curation, formal analysis, collected literature data, and edited the manuscript. E.M.E.-F.: Conceptualization, formal analysis, data curation, collected literature data, wrote and edited the manuscript. All authors have read and agreed to the published version of the manuscript.

Funding: This research received no external funding.

Institutional Review Board Statement: Not Applicable.

Conflicts of Interest: No potential conflict of interest was reported by the authors.

\section{References}

1. Sedgwick, A.E.; D'Souza-Schorey, C. The biology of extracellular microvesicles. Traffic 2018, 19, 319-327. [CrossRef]

2. Van Niel, G.; D'Angelo, G.; Raposo, G. Shedding light on the cell biology of extracellular vesicles. Nat. Rev. Mol. Cell Biol. 2018, 19, 213-228. [CrossRef]

3. Zaborowski, M.P.; Balaj, L.; Breakefield, X.O.; Lai, C.P. Extracellular Vesicles: Composition, Biological Relevance, and Methods of Study. Bioscience 2015, 65, 783-797. [CrossRef]

4. Kalra, H.; Drummen, G.P.C.; Mathivanan, S. Focus on Extracellular Vesicles: Introducing the Next Small Big Thing. Int. J. Mol. Sci. 2016, 17, 170. [CrossRef]

5. György, B.; Szabó, T.G.; Pásztói, M.; Pál, Z.; Misják, P.; Aradi, B.; László, V.; Pállinger, É.; Pap, E.; Kittel, Á.; et al. Membrane vesicles, current state-of-the-art: Emerging role of extracellular vesicles. Cell. Mol. Life Sci. 2011, 68, 2667-2688. [CrossRef]

6. Yuana, Y.; Sturk, A.; Nieuwland, R. Extracellular vesicles in physiological and pathological conditions. Blood Rev. 2013, 27, 31-39. [CrossRef]

7. Robbins, P.D.; Morelli, A.E. Regulation of immune responses by extracellular vesicles. Nat. Rev. Immunol. 2014, 14, 195-208. [CrossRef] [PubMed]

8. Frühbeis, C.; Fröhlich, D.; Kuo, W.P.; Amphornrat, J.; Thilemann, S.; Saab, A.S.; Kirchhoff, F.; Möbius, W.; Goebbels, S.; Nave, K.-A.; et al. Neurotransmitter-Triggered Transfer of Exosomes Mediates Oligodendrocyte-Neuron Communication. PLoS Biol. 2013, 11, e1001604. [CrossRef]

9. Holm, M.M.; Kaiser, J.; Schwab, M.E. Extracellular Vesicles: Multimodal Envoys in Neural Maintenance and Repair. Trends Neurosci. 2018, 41, 360-372. [CrossRef]

10. Silverman, J.M.; Reiner, N.E. Exosomes and other microvesicles in infection biology: Organelles with unanticipated phenotypes. Cell. Microbiol. 2010, 13, 1-9. [CrossRef]

11. Schorey, J.S.; Cheng, Y.; Singh, P.P.; Smith, V.L. Exosomes and other extracellular vesicles in host-pathogen interactions. EMBO Rep. 2015, 16, 24-43. [CrossRef] 
12. Nogués, L.; Benito-Martin, M.; Hergueta-Redondo, M.; Peinado, H. The influence of tumour-derived extracellular vesicles on local and distal metastatic dissemination. Mol. Asp. Med. 2018, 60, 15-26. [CrossRef]

13. Xu, R.; Rai, A.; Chen, M.; Suwakulsiri, W.; Greening, D.; Simpson, R. Extracellular vesicles in cancer-Implications for future improvements in cancer care. Nat. Rev. Clin. Oncol. 2018, 15, 617-638. [CrossRef]

14. Kouwaki, T.; Fukushima, Y.; Daito, T.; Sanada, T.; Yamamoto, N.; Mifsud, E.J.; Leong, C.R.; Tsukiyama-Kohara, K.; Kohara, M.; Matsumoto, M.; et al. Extracellular Vesicles Including Exosomes Regulate Innate Immune Responses to Hepatitis B Virus Infection. Front. Immunol. 2016, 7, 335. [CrossRef]

15. Meckes, D.G.; Raab-Traub, N. Microvesicles and Viral Infection. J. Virol. 2011, 85, 12844-12854. [CrossRef]

16. Altan-Bonnet, N. Extracellular vesicles are the Trojan horses of viral infection. Curr. Opin. Microbiol. 2016, 32, 77-81. [CrossRef]

17. Anderson, M.R.; Kashanchi, F.; Jacobson, S. Exosomes in Viral Disease. Neurotherapeuthics 2016, 13, 535-546. [CrossRef]

18. Meckes, D.G. Exosomal Communication Goes Viral. J. Virol. 2015, 89, 5200-5203. [CrossRef]

19. Nolte, E.; Hoen, T.; Cremer, T.; Gallo, R.C.; Margolis, L.B. Extracellular vesicles and viruses: Are they close relatives. Proc. Natl. Acad. Sci. USA 2016, 113, 9155-9161. [CrossRef]

20. Mitchell, P.; Petfalski, E.; Shevchenko, A.; Mann, M.; Tollervey, D. The exosome: A conserved eukaryotic RNA processing complex containing multiple $3^{\prime} \rightarrow 5^{\prime}$ exoribonucleases. Cell 1997, 91, 457-466. [CrossRef]

21. Colombo, M.; Moita, C.; van Niel, G.; Kowal, J.; Vigneron, J.; Benaroch, P.; Manel, N.; Moita, L.F.; Théry, C.; Raposo, G. Analysis of ESCRT functions in exosome biogenesis, composition and secretion highlights the heterogeneity of extracellular vesicles. J. Cell Sci. 2013, 126, 5553-5565. [CrossRef]

22. Théry, C.; Zitvogel, L.; Amigorena, S. Exosomes: Composition, biogenesis and function. Nat. Rev. Immunol. 2002, 2, 569-579. [CrossRef]

23. Pan, B.-T.; Johnstone, R.M. Fate of the transferrin receptor during maturation of sheep reticulocytes in vitro: Selective externalization of the receptor. Cell 1983, 33, 967-978. [CrossRef]

24. Johnstone, R.M.; Adam, M.; Hammond, J.R.; Orr, L.; Turbide, C. Vesicle formation during reticulocyte maturation. Association of plasma membrane activities with released vesicles (exosomes). J. Biol. Chem. 1987, 262, 9412-9420. [CrossRef]

25. Akers, J.C.; Gonda, D.; Kim, R.; Carter, B.S.; Chen, C.C. Biogenesis of extracellular vesicles (EV): Exosomes, microvesicles, retrovirus-like vesicles, and apoptotic bodies. J. Neuro Oncol. 2013, 113, 1-11. [CrossRef]

26. Théry, C.; Witwer, K.W.; Aikawa, E.; Alcaraz, M.J.; Anderson, J.D.; Andriantsitohaina, R.; Antoniou, A.; Arab, T.; Archer, F.; Atkin-Smith, G.K.; et al. Minimal information for studies of extracellular vesicles 2018 (MISEV2018): A position statement of the International Society for Extracellular Vesicles and update of the MISEV2014 guidelines. J. Extracell. Vesicles 2018, 7, 1535750. [CrossRef]

27. Doyle, L.M.; Wang, M.Z. Overview of Extracellular Vesicles, Their Origin, Composition, Purpose, and Methods for Exosome Isolation and Analysis. Cells 2019, 8, 727. [CrossRef]

28. Dang, V.D.; Jella, K.K.; Ragheb, R.R.T.; Denslow, N.D.; Alli, A.A. Lipidomic and proteomic analysis of exosomes from mouse cortical collecting duct cells. FASEB J. 2017, 31, 5399-5408. [CrossRef]

29. Ridder, K.; Keller, S.; Dams, M.; Rupp, A.-K.; Schlaudraff, J.; Del Turco, D.; Starmann, J.; Macas, J.; Karpova, D.; Devraj, K.; et al. Extracellular Vesicle-Mediated Transfer of Genetic Information between the Hematopoietic System and the Brain in Response to Inflammation. PLoS Biol. 2014, 12, e1001874. [CrossRef]

30. Elmore, S. Apoptosis: A review of programmed cell death. Toxicol. Pathol. 2007, 35, 495-516. [CrossRef]

31. Kerr, J.F.R.; Wyllie, A.H.; Currie, A. A basic biological phenomenon with wideranging implications in tissue kinetics. Br. J. Cancer 1972, 26, 239. [CrossRef] [PubMed]

32. Bao, Q.; Shi, Y. Apoptosome: A platform for the activation of initiator caspases. Cell Death Differ. 2007, 14, 56-65. [CrossRef]

33. Cocucci, E.; Racchetti, G.; Meldolesi, J. Shedding microvesicles: Artefacts no more. Trends Cell Biol. 2009, 19, 43-51. [CrossRef] [PubMed]

34. Van der Pol, E.; Böing, A.N.; Harrison, P.; Sturk, A.; Nieuwland, R. Classification, functions, and clinical relevance of extracellular vesicles. Pharmacol. Rev. 2012, 64, 676-705. [CrossRef]

35. Smolarz, M.; Pietrowska, M.; Matysiak, N.; Mielańczyk, Ł.; Widłak, P. Proteome Profiling of Exosomes Purified from a Small Amount of Human Serum: The Problem of Co-Purified Serum Components. Proteomes 2019, 7, 18. [CrossRef]

36. De Toro, J.; Herschlik, L.; Waldner, C.; Mongini, C. Emerging Roles of Exosomes in Normal and Pathological Conditions: New Insights for Diagnosis and Therapeutic Applications. Front. Immunol. 2015, 6, 203. [CrossRef]

37. Lässer, C.; Alikhani, V.S.; Ekström, K.; Eldh, M.; Paredes, P.T.; Bossios, A.; Sjöstrand, M.; Gabrielsson, S.; Lötvall, J.; Valadi, H. Human saliva, plasma and breast milk exosomes contain RNA: Uptake by macrophages. J. Transl. Med. 2011, 9, 1-8. [CrossRef]

38. Street, J.M.; Barran, P.E.; Mackay, C.L.; Weidt, S.; Balmforth, C.; Walsh, T.S.; Chalmers, R.T.A.; Webb, D.J.; Dear, J.W. Identification and proteomic profiling of exosomes in human cerebrospinal fluid. J. Transl. Med. 2012, 10, 5. [CrossRef]

39. Madison, M.N.; Roller, R.J.; Okeoma, C.M. Human semen contains exosomes with potent anti-HIV-1 activity. Retrovirology 2014, 11, 1-16. [CrossRef]

40. Villanueva, M.T. Microenvironment: Small containers, important cargo. Nat. Rev. Cancer 2014, 14, 764. [CrossRef]

41. Pant, S.; Hilton, H.; Burczynski, M.E. The multifaceted exosome: Biogenesis, role in normal and aberrant cellular function, and frontiers for pharmacological and biomarker opportunities. Biochem. Pharmacol. 2012, 83, 1484-1494. [CrossRef] [PubMed]

42. Hurley, J.H.; Odorizzi, G. Get on the exosome bus with ALIX. Nat. Cell Biol. 2012, 14, 654-655. [CrossRef] 
43. Stoorvogel, W. Resolving sorting mechanisms into exosomes. Cell Res. 2015, 25, 531-532. [CrossRef]

44. Bowden, T.J.; Kraev, I.; Lange, S. Extracellular Vesicles and Post-Translational Protein Deimination Signatures in Mollusca-The Blue Mussel (Mytilus edulis), Soft Shell Clam (Mya arenaria), Eastern Oyster (Crassostrea virginica) and Atlantic Jacknife Clam (Ensis leei). Biology 2020, 9, 416. [CrossRef]

45. Bowden, T.J.; Kraev, I.; Lange, S. Extracellular vesicles and post-translational protein deimination signatures in haemolymph of the American lobster (Homarus americanus). Fish Shellfish. Immunol. 2020, 106, 79-102. [CrossRef] [PubMed]

46. Azmi, A.S.; Bao, B.; Sarkar, F.H. Exosomes in cancer development, metastasis, and drug resistance: A comprehensive review. Cancer Metastasis Rev. 2013, 32, 623-642. [CrossRef]

47. Beckler, M.D.; Higginbotham, J.N.; Franklin, J.L.; Ham, A.-J.; Halvey, P.J.; Imasuen, I.E.; Whitwell, C.; Li, M.; Liebler, D.; Coffey, R.J. Proteomic Analysis of Exosomes from Mutant KRAS Colon Cancer Cells Identifies Intercellular Transfer of Mutant KRAS. Mol. Cell. Proteom. 2013, 12, 343-355. [CrossRef]

48. Kosaka, N. Decoding the Secret of Cancer by Means of Extracellular Vesicles. J. Clin. Med. 2016, 5, 22. [CrossRef]

49. Takahashi, K.; Yan, I.K.; Wood, J.; Haga, H.; Patel, T. Involvement of Extracellular Vesicle Long Noncoding RNA (linc-VLDLR) in Tumor Cell Responses to Chemotherapy. Mol. Cancer Res. 2014, 12, 1377-1387. [CrossRef] [PubMed]

50. Chaput, N.; Taïeb, J.; André, F.; Zitvogel, L. The potential of exosomes in immunotherapy. Expert Opin. Biol. Ther. 2005, 5, 737-747. [CrossRef]

51. Li, S.; Li, S.; Wu, S.; Chen, L. Exosomes Modulate the Viral Replication and Host Immune Responses in HBV Infection. Biomed. Res. Int. 2019, 1-9. [CrossRef] [PubMed]

52. Longatti, A.; Boyd, B.; Chisari, F.V. Virion-Independent Transfer of Replication-Competent Hepatitis C Virus RNA between Permissive Cells. J. Virol. 2015, 89, 2956-2961. [CrossRef]

53. Théry, C.; Ostrowski, M.; Segura, E. Membrane vesicles as conveyors of immune responses. Nat. Rev. Immunol. 2009, 9, 581-593 [CrossRef] [PubMed]

54. Mathivanan, S.; Lim, J.W.E.; Tauro, B.J.; Ji, H.; Moritz, R.L.; Simpson, R.J. Proteomics Analysis of A33 Immunoaffinity-purified Exosomes Released from the Human Colon Tumor Cell Line LIM1215 Reveals a Tissue-specific Protein Signature. Mol. Cell. Proteom. 2010, 9, 197-208. [CrossRef]

55. Van Niel, G.; Porto-Carreiro, I.; Simoes, S.; Raposo, G. Exosomes: A Common Pathway for a Specialized Function. J. Biochem. 2006, 140, 13-21. [CrossRef]

56. Lydic, T.A.; Townsend, S.; Adda, C.G.; Collins, C.; Mathivanan, S.; Reid, G.E. Rapid and comprehensive 'shotgun' lipidome profiling of colorectal cancer cell derived exosomes. Methods 2015, 87, 83-95. [CrossRef]

57. Subra, C.; Laulagnier, K.; Perret, B.; Record, M. Exosome lipidomics unravels lipid sorting at the level of multivesicular bodies. Biochimie 2007, 89, 205-212. [CrossRef] [PubMed]

58. Brouwers, J.F.; Aalberts, M.; Jansen, J.W.A.; Van Niel, G.; Wauben, M.; Stout, T.A.E.; Helms, J.B.; Stoorvogel, W. Distinct lipid compositions of two types of human prostasomes. Proteomics 2013, 13, 1660-1666. [CrossRef]

59. Matsuo, H.; Chevallier, J.; Mayran, N.; Le Blanc, I.; Ferguson, C.; Fauré, J.; Blanc, N.S.; Matile, S.; Dubochet, J.; Sadoul, R.; et al. Role of LBPA and Alix in Multivesicular Liposome Formation and Endosome Organization. Science 2004, 303, 531-534. [CrossRef]

60. Subra, C.; Grand, D.; Laulagnier, K.; Stella, A.; Lambeau, G.; Paillasse, M.; De Medina, P.; Monsarrat, B.; Perret, B.; Silvente-Poirot, S.; et al. Exosomes account for vesicle-mediated transcellular transport of activatable phospholipases and prostaglandins. J. Lipid Res. 2010, 51, 2105-2120. [CrossRef]

61. Conde-Vancells, J.; Rodriguez-Suarez, E.; Embade, N.; Gil, D.; Matthiesen, R.; Valle, M.; Elortza, F.; Lu, S.C.; Mato, J.M.; FalconPerez, J.M. Characterization and Comprehensive Proteome Profiling of Exosomes Secreted by Hepatocytes. J. Proteome Res. 2008, 7, 5157-5166. [CrossRef]

62. Batista, B.S.; Eng, W.S.; Pilobello, K.T.; Hendricks-Muñoz, K.D.; Mahal, L.K. Identification of a Conserved Glycan Signature for Microvesicles. J. Proteome Res. 2011, 10, 4624-4633. [CrossRef]

63. Saunderson, S.; Dunn, A.C.; Crocker, P.; McLellan, A.D. CD169 mediates the capture of exosomes in spleen and lymph node. Blood J. Am. Soc. Hematol. 2014, 123, 208-216. [CrossRef]

64. Valadi, H.; Ekström, K.; Bossios, A.; Sjöstrand, M.; Lee, J.J.; Lötvall, J.O. Exosome-mediated transfer of mRNAs and microRNAs is a novel mechanism of genetic exchange between cells. Nat. Cell Biol. 2007, 9, 654-659. [CrossRef]

65. Schorey, J.S.; Bhatnagar, S. Exosome Function: From Tumor Immunology to Pathogen Biology. Traffic 2008, 9, 871-881. [CrossRef]

66. Bhatnagar, S.; Shinagawa, K.; Castellino, F.J.; Schorey, J.S. Exosomes released from macrophages infected with intracellular pathogens stimulate a proinflammatory response in vitro and in vivo. Blood 2007, 110, 3234-3244. [CrossRef]

67. McAndrews, K.M.; Kalluri, R. Mechanisms associated with biogenesis of exosomes in cancer. Mol. Cancer 2019, 18, 1-11. [CrossRef]

68. Williams, R.L.; Urbé, S. The emerging shape of the ESCRT machinery. Nat. Rev. Mol. Cell Biol. 2007, 8, 355-368. [CrossRef] [PubMed]

69. Kennedy, M.J.; Ehlers, M.D. Mechanisms and function of dendritic exocytosis. Neuron 2011, 69, 856-875. [CrossRef]

70. Mashouri, L.; Yousefi, H.; Aref, A.R.; Ahadi, A.M.; Molaei, F.; Alahari, S.K. Exosomes: Composition, biogenesis, and mechanisms in cancer metastasis and drug resistance. Mol. Cancer 2019, 18, 1-14. [CrossRef]

71. Kalluri, R.; LeBleu, V.S. The biology, function, and biomedical applications of exosomes. Science 2020, 367, 6478. [CrossRef] 
72. Juan, T.; Fürthauer, M. Biogenesis and function of ESCRT-dependent extracellular vesicles. Semin. Cell Dev. Biol. 2018, 74, 66-77. [CrossRef]

73. Babst, M. MVB vesicle formation: ESCRT-dependent, ESCRT-independent and everything in between. Curr. Opin. Cell Biol. 2011, 23, 452-457. [CrossRef] [PubMed]

74. Janas, T.; Janas, M.M.; Sapon, K.; Janas, T. Mechanisms of RNA loading into exosomes. FEBS Lett. 2015, 589, 1391-1398. [CrossRef] [PubMed]

75. Izquierdo-Useros, N.; Lorizate, M.; Puertas, M.C.; Rodriguez-Plata, M.T.; Zangger, N.; Erikson, E.; Pino, M.; Erkizia, I.; Glass, B.; Clotet, B.; et al. Siglec-1 Is a Novel Dendritic Cell Receptor That Mediates HIV-1 Trans-Infection through Recognition of Viral Membrane Gangliosides. PLoS Biol. 2012, 10, e1001448. [CrossRef] [PubMed]

76. Van Dongen, H.M.; Masoumi, N.; Witwer, K.W.; Pegtel, D.M. Extracellular Vesicles Exploit Viral Entry Routes for Cargo Delivery. Microbiol. Mol. Biol. Rev. 2016, 80, 369-386. [CrossRef] [PubMed]

77. Zhang, Y.; Bergelson, J.M. Adenovirus receptors. J. Virol. 2005, 79, 12125-12131. [CrossRef] [PubMed]

78. Cheruiyot, C.; Pataki, Z.; Ramratnam, B.; Li, M. Proteomic Analysis of Exosomes and Its Application in HIV-1 Infection. Proteomics Clin. Appl. 2018, 12, 1-6. [CrossRef]

79. Thery, C.; Boussac, M.; Veron, P.; Ricciardi-Castagnoli, P.; Raposo, G.; Garin, J.; Amigorena, S. Proteomic analysis of dendritic cell-derived exosomes: A secreted subcellular compartment distinct from apoptotic vesicles. J. Immunol. 2001, 166, 7309-7318. [CrossRef]

80. Alenquer, M.; Amorim, M.J. Exosome Biogenesis, Regulation, and Function in Viral Infection. Viruses 2015, 7, 5066-5083. [CrossRef]

81. Temme, S.; Eis-Hübinger, A.M.; McLellan, A.D.; Koch, N. The Herpes Simplex Virus-1 Encoded Glycoprotein B Diverts HLA-DR into the Exosome Pathway. J. Immunol. 2010, 184, 236-243. [CrossRef]

82. Abels, E.R.; Breakefield, X.O. Introduction to Extracellular Vesicles: Biogenesis, RNA Cargo Selection, Content, Release, and Uptake; Springer: Berlin/Heidelberg, Germany, 2016.

83. Kalamvoki, M.; Du, T.; Roizman, B. Cells infected with herpes simplex virus 1 export to uninfected cells exosomes containing STING, viral mRNAs, and microRNAs. Proc. Natl. Acad. Sci. USA 2014, 111, E4991-E4996. [CrossRef]

84. Pleet, M.L.; Mathiesen, A.; DeMarino, C.; Akpamagbo, Y.A.; Barclay, R.A.; Schwab, A.; Iordanskiy, S.; Sampey, G.C.; Lepene, B.; Ilinykh, P.A.; et al. Corrigendum: Ebola VP40 in exosomes can cause immune cell dysfunction. Front. Microbiol. $2018,9,692$. [CrossRef]

85. Pleet, M.L.; Erickson, J.; DeMarino, C.; Barclay, R.A.; Cowen, M.; Lepene, B.; Liang, J.; Kuhn, J.H.; Prugar, L.; Stonier, S.W.; et al. Ebola Virus VP40 Modulates Cell Cycle and Biogenesis of Extracellular Vesicles. J. Infect. Dis. 2018, 218, S365-S387. [CrossRef]

86. Pegtel, D.M.; Cosmopoulos, K.; Thorley-Lawson, D.A.; van Eijndhoven, M.A.J.; Hopmans, E.S.; Lindenberg, J.L.; de Gruijl, T.D.; Würdinger, T.; Middeldorp, J.M. Functional delivery of viral miRNAs via exosomes. Proc. Natl. Acad. Sci. USA 2010, 107, 6328-6333. [CrossRef]

87. Ahmed, W.; Philip, P.S.; Attoub, S.; Khan, G. Epstein-Barr virus-infected cells release Fas ligand in exosomal fractions and induce apoptosis in recipient cells via the extrinsic pathway. J. Gen. Virol. 2015, 96, 3646-3659. [CrossRef]

88. Vallhov, H.; Gutzeit, C.; Johansson, S.M.; Nagy, N.; Paul, M.; Li, Q.; Friend, S.; George, T.C.; Klein, E.; Scheynius, A.; et al. Exosomes containing glycoprotein 350 released by EBV-transformed B cells selectively target B cells through CD21 and block EBV infection in vitro. J. Immunol. 2011, 186, 73-82. [CrossRef] [PubMed]

89. Ikeda, M.; Longnecker, R. Cholesterol is critical for Epstein-Barr virus latent membrane protein 2A trafficking and protein stability. Virology 2007, 360, 461-468. [CrossRef] [PubMed]

90. Flanagan, J.; Middeldorp, J.; Sculley, T. Localization of the Epstein-Barr virus protein LMP 1 to exosomes. J. Gen. Virol. 2003, 84, 1871-1879. [CrossRef] [PubMed]

91. Ahmed, W.; Philip, P.S.; Tariq, S.; Khan, G. Epstein-Barr Virus-Encoded Small RNAs (EBERs) Are Present in Fractions Related to Exosomes Released by EBV-Transformed Cells. PLoS ONE 2014, 9, e99163. [CrossRef]

92. Ramakrishnaiah, V.; Thumann, C.; Fofana, I.; Habersetzer, F.; Pan, Q.; de Ruiter, P.E.; Willemsen, R.; Demmers, J.A.A.; Raj, V.S.; Jenster, G.; et al. Exosome-mediated transmission of hepatitis $\mathrm{C}$ virus between human hepatoma Huh7.5 cells. Proc. Natl. Acad. Sci. USA 2013, 110, 13109-13113. [CrossRef]

93. Bukong, T.N.; Momen-Heravi, F.; Kodys, K.; Bala, S.; Szabo, G. Exosomes from Hepatitis C Infected Patients Transmit HCV Infection and Contain Replication Competent Viral RNA in Complex with Ago2-miR122-HSP90. PLOS Pathog. 2014, 10, e1004424. [CrossRef]

94. Dreux, M.; Garaigorta, U.; Boyd, B.; Décembre, E.; Chung, J.; Whitten-Bauer, C.; Wieland, S.; Chisari, F.V. Short-Range Exosomal Transfer of Viral RNA from Infected Cells to Plasmacytoid Dendritic Cells Triggers Innate Immunity. Cell Host Microbe 2012, 12, 558-570. [CrossRef]

95. Zhu, X.; He, Z.; Yuan, J.; Wen, W.; Huang, X.; Hu, Y.; Lin, C.; Pan, J.; Li, R.; Deng, H.; et al. IFITM3-containing exosome as a novel mediator for anti-viral response in dengue virus infection. Cell. Microbiol. 2015, 17, 105-118. [CrossRef]

96. Honegger, A.; Schilling, D.; Bastian, S.; Sponagel, J.; Kuryshev, V.; Sültmann, H.; Scheffner, M.; Hoppe-Seyler, K.; Hoppe-Seyler, F. Dependence of Intracellular and Exosomal microRNAs on Viral E6/E7 Oncogene Expression in HPV-positive Tumor Cells. PLoS Pathog. 2015, 11, e1004712. [CrossRef] [PubMed] 
97. Plazolles, N.; Humbert, J.; Vachot, L.; Verrier, B.; Hocke, C.; Halary, F. Pivotal Advance: The promotion of soluble DC-SIGN release by inflammatory signals and its enhancement of cytomegalovirus-mediated cis-infection of myeloid dendritic cells. $J$. Leukoc. Biol. 2011, 89, 329-342. [CrossRef]

98. Morris-Love, J.; Gee, G.V.; O’Hara, B.A.; Assetta, B.; Atkinson, A.L.; Dugan, A.S.; Haley, S.A.; Atwood, W.J. JC Polyomavirus Uses Extracellular Vesicles To Infect Target Cells. mBio 2019, 10, 00379-19. [CrossRef]

99. Handala, L.; Blanchard, E.; Raynal, P.-I.; Roingeard, P.; Morel, V.; Descamps, V.; Castelain, S.; Francois, C.; Duverlie, G.; Brochot, E.; et al. BK Polyomavirus Hijacks Extracellular Vesicles for En Bloc Transmission. J. Virol. 2020, 94, 01834-19. [CrossRef]

100. Kim, M.H.; Lee, Y.H.; Seo, J.-W.; Moon, H.; Kim, J.S.; Kim, Y.G.; Jeong, K.-H.; Moon, J.-Y.; Lee, T.W.; Ihm, C.-G.; et al. Urinary exosomal viral microRNA as a marker of BK virus nephropathy in kidney transplant recipients. PLoS ONE 2017, 12, e0190068 [CrossRef]

101. Giannecchini, S. Evidence of the Mechanism by Which Polyomaviruses Exploit the Extracellular Vesicle Delivery System during Infection. Viruses 2020, 12, 585. [CrossRef]

102. Bomberger, J.; Lashua, L.; Fischer, D.; Hendricks, M. Exosome-Associated Iron Release during Respiratory Virus Co-Infection Enhances Pseudomonas aeruginosa Biofilm Growth. FASEB J. 2016, 30, 1223.

103. Caruso, S.; Poon, I.K.H. Apoptotic cell-derived extracellular vesicles: More than just debris. Front. Immunol. 2018, 9, 1486. [CrossRef]

104. Klase, Z.A.; Khakhina, S.; Schneider, A.D.B.; Callahan, M.V.; Glasspool-Malone, J.; Malone, R. Zika Fetal Neuropathogenesis: Etiology of a Viral Syndrome. PLoS Negl. Trop. Dis. 2016, 10, e0004877. [CrossRef] [PubMed]

105. Müller, J.A.; Harms, M.; Krüger, F.; Groß, R.; Joas, S.; Hayn, M.; Dietz, A.N.; Lippold, S.; Von Einem, J.; Schubert, A.; et al. Semen inhibits Zika virus infection of cells and tissues from the anogenital region. Nat. Commun. 2018, 9, 1-14. [CrossRef]

106. Zhou, W.; Woodson, M.; Sherman, M.B.; Neelakanta, G.; Sultana, H. Exosomes mediate Zika virus transmission through SMPD3 neutral Sphingomyelinase in cortical neurons. Emerg. Microbes Infect. 2019, 8, 307-326. [CrossRef]

107. Sampey, G.C.; Saifuddin, M.; Schwab, A.; Barclay, R.; Punya, S.; Chung, M.-C.; Hakami, R.M.; Zadeh, M.A.; Lepene, B.; Klase, Z.A.; et al. Exosomes from HIV-1-infected Cells Stimulate Production of Pro-inflammatory Cytokines through Trans-activating Response (TAR) RNA. J. Biol. Chem. 2016, 291, 1251-1266. [CrossRef]

108. Arenaccio, C.; Anticoli, S.; Manfredi, F.; Chiozzini, C.; Olivetta, E.; Federico, M. Latent HIV-1 is activated by exosomes from cells infected with either replication-competent or defective HIV-1. Retrovirology 2015, 12, 1-17. [CrossRef]

109. Sharp, P.M.H.; Hahn, B.H. BH: Origins of HIV and the AIDS pandemic. Cold Spring Harb. Perspect. Med. 2011, 1, a006841. [CrossRef] [PubMed]

110. Sato, K.; Aoki, J.; Misawa, N.; Daikoku, E.; Sano, K.; Tanaka, Y.; Koyanagi, Y. Modulation of Human Immunodeficiency Virus Type 1 Infectivity through Incorporation of Tetraspanin Proteins. J. Virol. 2008, 82, 1021-1033. [CrossRef]

111. Campbell, T.D.; Khan, M.; Huang, M.-B.; Bond, V.C.; Powell, M.D. HIV-1 Nef protein is secreted into vesicles that can fuse with target cells and virions. Ethn. Dis. 2008, 18, S2.

112. Yang, Y.; Han, Q.; Hou, Z.; Zhang, C.; Tian, Z.; Zhang, J. Exosomes mediate hepatitis B virus (HBV) transmission and NK-cell dysfunction. Cell. Mol. Immunol. 2017, 14, 465-475. [CrossRef]

113. Jiang, B.; Himmelsbach, K.; Ren, H.; Boller, K.; Hildt, E. Subviral Hepatitis B Virus Filaments, like Infectious Viral Particles, Are Released via Multivesicular Bodies. J. Virol. 2016, 90, 3330-3341. [CrossRef]

114. Longatti, A. The Dual Role of Exosomes in Hepatitis A and C Virus Transmission and Viral Immune Activation. Viruses 2015, 7, 6707-6715. [CrossRef]

115. Ahsan, N.A.; Sampey, G.C.; Lepene, B.; Akpamagbo, Y.; Barclay, R.A.; Iordanskiy, S.; Hakami, R.M.; Kashanchi, F. Presence of Viral RNA and Proteins in Exosomes from Cellular Clones Resistant to Rift Valley Fever Virus Infection. Front. Microbiol. 2016, 7, 139. [CrossRef] [PubMed]

116. Shembade, N.; Harhaj, E.W. Role of post-translational modifications of HTLV-1 Tax in NF-kB activation. World J. Biol. Chem. 2010, 1, 13. [CrossRef] [PubMed]

117. Dhib-Jalbut, S.; Hoffman, P.M.; Yamabe, T.; Sun, D.; Xia, J.; Eisenberg, H.; Bergey, G.; Ruscetti, F.W. Extracellular human T-cell lymphotropic virus type I tax protein induces cytokine production in adult human microglial cells. Ann. Neurol. 1994, 36, 787-790. [CrossRef]

118. Jaworski, E.; Narayanan, A.; Van Duyne, R.; Shabbeer-Meyering, S.; Iordanskiy, S.; Saifuddin, M.; Das, R.; Afonso, P.; Sampey, G.C.; Chung, M.; et al. Human T-lymphotropic Virus Type 1-infected Cells Secrete Exosomes That Contain Tax Protein. J. Biol. Chem. 2014, 289, 22284-22305. [CrossRef]

119. Pfeffer, S.; Zavolan, M.; Grässer, F.A.; Chien, M.; Russo, J.J.; Ju, J.; John, B.; Enright, A.; Marks, D.; Sander, C.; et al. Identification of Virus-Encoded MicroRNAs. Science 2004, 304, 734-736. [CrossRef]

120. Hoshina, S.; Sekizuka, T.; Kataoka, M.; Hasegawa, H.; Hamada, H.; Kuroda, M.; Katano, H. Profile of Exosomal and Intracellular microRNA in Gamma-Herpesvirus-Infected Lymphoma Cell Lines. PLoS ONE 2016, 11, e0162574. [CrossRef] [PubMed]

121. Chahar, H.S.; Bao, X.; Casola, A. Exosomes and Their Role in the Life Cycle and Pathogenesis of RNA Viruses. Viruses 2015, 7, 3204-3225. [CrossRef]

122. Madison, M.N.; Okeoma, C.M. Exosomes: Implications in HIV-1 Pathogenesis. Viruses 2015, 7, 4093-4118. [CrossRef]

123. Madison, M.N.; Jones, P.; Okeoma, C.M. Exosomes in human semen restrict HIV-1 transmission by vaginal cells and block intravaginal replication of LP-BM5 murine AIDS virus complex. Virology 2015, 482, 189-201. [CrossRef] 
124. Mori, Y.; Koike, M.; Moriishi, E.; Kawabata, A.; Tang, H.; Oyaizu, H.; Uchiyama, Y.; Yamanishi, K. Human Herpesvirus-6 Induces MVB Formation, and Virus Egress Occurs by an Exosomal Release Pathway. Traffic 2008, 9, 1728-1742. [CrossRef] [PubMed]

125. Bissig, C.; Gruenberg, J. ALIX and the multivesicular endosome: ALIX in Wonderland. Trends Cell Biol. 2014, 24, 19-25. [CrossRef] [PubMed]

126. Gan, X.; Gould, S.J. Identification of an inhibitory budding signal that blocks the release of HIV particles and exosome/microvesicle proteins. Mol. Biol. Cell 2011, 22, 817-830. [CrossRef]

127. Sampey, G.C.; Meyering, S.S.; Zadeh, M.A.; Saifuddin, M.; Hakami, R.M.; Kashanchi, F. Exosomes and their role in CNS viral infections. J. Neurovirol. 2014, 20, 199-208. [CrossRef] [PubMed]

128. Trajkovic, K.; Hsu, C.; Chiantia, S.; Rajendran, L.; Wenzel, D.; Wieland, F.; Schwille, P.; Brugger, B.; Simons, M. Ceramide Triggers Budding of Exosome Vesicles into Multivesicular Endosomes. Science 2008, 319, 1244-1247. [CrossRef] [PubMed]

129. Perez-Hernandez, D.; Gutiérrez-Vázquez, C.; Jorge, I.; López-Martín, S.; Ursa, A.; Sánchez-Madrid, F.; Vázquez, J.; Yáñez-Mó, M. The Intracellular Interactome of Tetraspanin-enriched Microdomains Reveals Their Function as Sorting Machineries toward Exosomes. J. Biol. Chem. 2013, 288, 11649-11661. [CrossRef]

130. Van Niel, G.; Charrin, S.; Simoes, S.; Romao, M.; Rochin, L.; Saftig, P.; Marks, M.S.; Rubinstein, E.; Raposo, G. The tetraspanin CD63 regulates ESCRT-independent and -dependent endosomal sorting during melanogenesis. Dev. Cell 2011, 21, 708-721. [CrossRef]

131. Stuffers, S.; Wegner, C.S.; Stenmark, H.; Brech, A. Multivesicular endosome biogenesis in the absence of ESCRTs. Traffic 2009, 10, 925-937. [CrossRef]

132. Tamai, K.; Tanaka, N.; Nakano, T.; Kakazu, E.; Kondo, Y.; Inoue, J.; Shiina, M.; Fukushima, K.; Hoshino, T.; Sano, K.; et al. Exosome secretion of dendritic cells is regulated by Hrs, an ESCRT-0 protein. Biochem. Biophys. Res. Commun. 2010, 399, 384-390. [CrossRef]

133. Schwartz, S.L.; Cao, C.; Pylypenko, O.; Rak, A.; Wandinger-Ness, A. Rab GTPases at a glance. J. Cell Sci. 2007, 120, 3905-3910. [CrossRef]

134. Baietti, M.F.; Zhang, Z.; Mortier, E.; Melchior, A.; Degeest, G.; Geeraerts, A.; Ivarsson, Y.; Depoortere, F.; Coomans, C.; Vermeiren, E.; et al. Syndecan-syntenin-ALIX regulates the biogenesis of exosomes. Nat. Cell Biol. 2012, 14, 677-685. [CrossRef] [PubMed]

135. Colombo, M.; Raposo, G.; Théry, C. Biogenesis, secretion, and intercellular interactions of exosomes and other extracellular vesicles. Annu. Rev. Cell Dev. Biol. 2014, 30, 255-289. [CrossRef] [PubMed]

136. Fader, C.M.; Sánchez, D.G.; Mestre, M.B.; Colombo, M.I. TI-VAMP/VAMP7 and VAMP3/cellubrevin: Two v-SNARE proteins involved in specific steps of the autophagy/multivesicular body pathways. Biochim. Biophys. Acta BBA Mol. Cell Res. 2009, 1793, 1901-1916. [CrossRef]

137. Savina, A.; Fader, C.M.; Damiani, M.T.; Colombo, M.I. Rab11 Promotes Docking and Fusion of Multivesicular Bodies in a Calcium-Dependent Manner. Traffic 2005, 6, 131-143. [CrossRef]

138. Livshits, M.A.; Khomyakova, E.; Evtushenko, E.; Lazarev, V.N.; Kulemin, N.; Semina, S.E.; Generozov, E.; Govorun, V.M. Isolation of exosomes by differential centrifugation: Theoretical analysis of a commonly used protocol. Sci. Rep. 2015, 5, 1-14. [CrossRef]

139. Johnstone, R.M. Maturation of reticulocytes: Formation of exosomes as a mechanism for shedding membrane proteins. Biochem. Cell Biol. 1992, 70, 179-190. [CrossRef]

140. Théry, C.; Amigorena, S.; Raposo, G.; Clayton, A. Isolation and Characterization of Exosomes from Cell Culture Supernatants and Biological Fluids. Curr. Protoc. Cell Biol. 2006, 30, 3-22. [CrossRef]

141. Cvjetkovic, A.; Lötvall, J.; Lässer, C. The influence of rotor type and centrifugation time on the yield and purity of extracellular vesicles. J. Extracell. Vesicles 2014, 3, 23111. [CrossRef]

142. Böing, A.N.; van der Pol, E.; Grootemaat, A.E.; Coumans, F.A.W.; Sturk, A.; Nieuwland, R. Single-step isolation of extracellular vesicles by size-exclusion chromatography. J. Extracell. Vesicles 2014, 3, 23430. [CrossRef]

143. Cantin, R.; Diou, J.; Bélanger, D.; Tremblay, A.M.; Gilbert, C. Discrimination between exosomes and HIV-1: Purification of both vesicles from cell-free supernatants. J. Immunol. Methods 2008, 338, 21-30. [CrossRef] [PubMed]

144. Ford, T.; Graham, J.; Rickwood, D. Iodixanol: A Nonionic Iso-osmotic Centrifugation Medium for the Formation of Self-Generated Gradients. Anal. Biochem. 1994, 220, 360-366. [CrossRef]

145. Rider, M.A.; Hurwitz, S.N.; Meckes, D.G., Jr. ExtraPEG: A Polyethylene Glycol-Based Method for Enrichment of Extracellular Vesicles. Sci. Rep. 2016, 6, 23978. [CrossRef] [PubMed]

146. Vergauwen, G.; Dhondt, B.; Van Deun, J.; De Smedt, E.; Berx, G.; Timmerman, E.; Gevaert, K.; Miinalainen, I.; Cocquyt, V.; Braems, G.; et al. Confounding factors of ultrafiltration and protein analysis in extracellular vesicle research. Sci. Rep. 2017, 7, 1-12. [CrossRef]

147. Fitzgerald, J.; Leonard, P.; Darcy, E.; Sharma, S.; O’Kennedy, R. Immunoaffinity Chromatography: Concepts and Applications. Protein Chromatogr. 2017, 1485, 27-51. [CrossRef]

148. Li, P.; Kaslan, M.; Lee, S.H.; Yao, J.; Gao, Z. Progress in Exosome Isolation Techniques. Theranostics 2017, 7, 789-804. [CrossRef]

149. Zarovni, N.; Corrado, A.; Guazzi, P.; Zocco, D.; Lari, E.; Radano, G.; Muhhina, J.; Fondelli, C.; Gavrilova, J.; Chiesi, A. Integrated isolation and quantitative analysis of exosome shuttled proteins and nucleic acids using immunocapture approaches. Methods 2015, 87, 46-58. [CrossRef]

150. Wu, Y.; Deng, W.; Klinke, D.J., II. Exosomes: Improved methods to characterize their morphology, RNA content, and surface protein biomarkers. Analyst 2015, 140, 6631-6642. [CrossRef] 
151. Maas, S.L.N.; Broekman, M.; Nolte, M.L.D.; Hoen, T.; Mastrobattista, E.; Schiffelers, R.M.; Wauben, M.H.M.; Broekman, M.L.D.; Hoen, E.N.M. Possibilities and limitations of current technologies for quantification of biological extracellular vesicles and synthetic mimics. J. Control. Release 2015, 200, 87-96. [CrossRef] [PubMed]

152. Murray, C.J.L.; Ortblad, K.F.; Guinovart, C.; Lim, S.S.; Wolock, T.M.; Roberts, D.A.; Dansereau, E.A.; Graetz, N.; Barber, R.M.; Brown, J.C.; et al. Global, regional, and national incidence and mortality for HIV, tuberculosis, and malaria during 1990-2013: A systematic analysis for the Global Burden of Disease Study 2013. Lancet 2014, 384, 1005-1070. [CrossRef]

153. Zhang, W.; Jiang, X.; Bao, J.; Wang, Y.; Liu, H.; Tang, L. Exosomes in Pathogen Infections: A Bridge to Deliver Molecules and Link Functions. Front. Immunol. 2018, 9, 90. [CrossRef]

154. Izquierdo-Useros, N.; Puertas, M.C.; Borras, F.E.; Blanco, J.; Martinez-Picado, J. Exosomes and retroviruses: The chicken or the egg? Cell. Microbiol. 2011, 13, 10-17. [CrossRef]

155. Ott, D.E. Cellular proteins detected in HIV-1. Rev. Med Virol. 2008, 18, 159-175. [CrossRef]

156. Wubbolts, R.; Leckie, R.S.; Veenhuizen, P.T.M.; Schwarzmann, G.; Möbius, W.; Hoernschemeyer, J.; Slot, J.-S.; Geuze, H.J.; Stoorvogel, W. Proteomic and biochemical analyses of human B cell-derived exosomes Potential implications for their function and multivesicular body formation. J. Biol. Chem. 2003, 278, 10963-10972. [CrossRef]

157. Krishnamoorthy, L.; Bess, J.W.; Preston, A.B.; Nagashima, K.; Mahal, L.K. HIV-1 and microvesicles from T cells share a common glycome, arguing for a common origin. Nat. Chem. Biol. 2009, 5, 244-250. [CrossRef] [PubMed]

158. Grigorov, B.; Attuil-Audenis, V.; Perugi, F.; Nedelec, M.; Watson, S.; Pique, C.; Darlix, J.-L.; Conjeaud, H.; Muriaux, D. A role for CD81 on the late steps of HIV-1 replication in a chronically infected T cell line. Retrovirology 2009, 6, 28. [CrossRef]

159. Savina, A.; Vidal, M.; Colombo, M.I. The exosome pathway in K562 cells is regulated by Rab11. J. Cell Sci. 2002, 115, 2505-2515. [CrossRef]

160. Bruce, E.A.; Digard, P.; Stuart, A.D. The Rab11 Pathway Is Required for Influenza A Virus Budding and Filament Formation. J. Virol. 2010, 84, 5848-5859. [CrossRef]

161. Rowe, R.; Suszko, J.W.; Pekosz, A. Roles for the recycling endosome, Rab8, and Rab11 in hantavirus release from epithelial cells. Virology 2008, 382, 239-249. [CrossRef]

162. Utley, T.J.; Ducharme, N.; Varthakavi, V.; Shepherd, B.E.; Santangelo, P.J.; Lindquist, M.E.; Goldenring, J.R.; Crowe, J.E. Respiratory syncytial virus uses a Vps4-independent budding mechanism controlled by Rab11-FIP2. Proc. Natl. Acad. Sci. USA 2008, 105, 10209-10214. [CrossRef] [PubMed]

163. Abrami, L.; Brandi, L.; Moayeri, M.; Brown, M.J.; Krantz, B.A.; Leppla, S.H.; Van Der Goot, F.G. Hijacking Multivesicular Bodies Enables Long-Term and Exosome-Mediated Long-Distance Action of Anthrax Toxin. Cell Rep. 2013, 5, 986-996. [CrossRef]

164. Bhuin, T.; Roy, J.K. Rab11 in Disease Progression. Int. J. Mol. Cell. Med. 2015, 4, 1-8.

165. Ostrowski, M.; Carmo, N.B.; Krumeich, S.; Fanget, I.; Raposo, G.; Savina, A.; Moita, C.F.; Schauer, K.; Hume, A.N.; Freitas, R.P.; et al. Rab27a and Rab27b control different steps of the exosome secretion pathway. Nat. Cell Biol. 2010, 12, 19-30. [CrossRef] [PubMed]

166. Bobrie, A.; Krumeich, S.; Reyal, F.; Recchi, C.; Moita, L.; Seabra, M.; Ostrowski, M.; Théry, C. Rab27a Supports ExosomeDependent and -Independent Mechanisms That Modify the Tumor Microenvironment and Can Promote Tumor Progression. Cancer Res. 2012, 72, 4920-4930. [CrossRef]

167. Fraile-Ramos, A.; Cepeda, V.; Elstak, E.; Van Der Sluijs, P. Rab27a Is Required for Human Cytomegalovirus Assembly. PLoS ONE 2010, 5, e15318. [CrossRef]

168. Gerber, P.P.; Cabrini, M.; Jancic, C.; Paoletti, L.; Banchio, C.; Von Bilderling, C.; Sigaut, L.; Pietrasanta, L.; Duette, G.; Freed, E.O.; et al. Rab27a controls HIV-1 assembly by regulating plasma membrane levels of phosphatidylinositol 4,5-bisphosphate. J. Cell Biol. 2015, 209, 435-452. [CrossRef]

169. Meng, B.; Ip, N.C.Y.; Prestwood, L.J.; Abbink, T.E.M.; Lever, A.M.L. Evidence that the endosomal sorting complex required for transport-II (ESCRT-II) is required for efficient human immunodeficiency virus-1 (HIV-1) production. Retrovirology 2015, 12, 1-15. [CrossRef]

170. Miranda-Saksena, M.; Boadle, R.A.; Aggarwal, A.; Tijono, B.; Rixon, F.J.; Diefenbach, R.J.; Cunningham, A.L. Herpes Simplex Virus Utilizes the Large Secretory Vesicle Pathway for Anterograde Transport of Tegument and Envelope Proteins and for Viral Exocytosis from Growth Cones of Human Fetal Axons. J. Virol. 2009, 83, 3187-3199. [CrossRef]

171. Bello-Morales, R.; Crespillo, A.J.; Fraile-Ramos, A.; Tabarés, E.; Alcina, A.; López-Guerrero, J.A. Role of the small GTPase Rab27a during Herpes simplex virus infection of oligodendrocytic cells. BMC Microbiol. 2012, 12, 265. [CrossRef]

172. White, I.J.; Bailey, L.M.; Aghakhani, M.R.; Moss, S.E.; Futter, C.E. EGF stimulates annexin 1-dependent inward vesiculation in a multivesicular endosome subpopulation. EMBO J. 2006, 25, 1-12. [CrossRef]

173. Morales-Sánchez, A.; Fuentes-Pananá, E.M. Human Viruses and Cancer. Viruses 2014, 6, 4047-4079. [CrossRef]

174. Chugh, P.E.; Sin, S.-H.; Ozgur, S.; Henry, D.H.; Menezes, P.; Griffith, J.; Eron, J.J.; Damania, B.; Dittmer, D.P. Systemically Circulating Viral and Tumor-Derived MicroRNAs in KSHV-Associated Malignancies. PLoS Pathog. 2013, 9, e1003484. [CrossRef]

175. Canitano, A.; Venturi, G.; Borghi, M.; Ammendolia, M.G.; Fais, S. Exosomes released in vitro from Epstein-Barr virus (EBV)infected cells contain EBV-encoded latent phase mRNAs. Cancer Lett. 2013, 337, 193-199. [CrossRef]

176. Meckes, D.G.; Gunawardena, H.P.; Dekroon, R.M.; Heaton, P.R.; Edwards, R.H.; Ozgur, S.; Griffith, J.D.; Damania, B.; Raab-Traub, N. Modulation of B-cell exosome proteins by gamma herpesvirus infection. Proc. Natl. Acad. Sci. USA 2013, 110, E2925-E2933. [CrossRef] 
177. Edwards, R.H.; Marquitz, A.R.; Raab-Traub, N. Epstein-Barr Virus BART MicroRNAs Are Produced from a Large Intron prior to Splicing. J. Virol. 2008, 82, 9094-9106. [CrossRef] [PubMed]

178. Hooykaas, M.J.G.; Kruse, E.; Wiertz, E.J.H.J.; Lebbink, R.J. Comprehensive profiling of functional Epstein-Barr virus miRNA expression in human cell lines. BMC Genom. 2016, 17, 1-13. [CrossRef]

179. Shinozaki-Ushiku, A.; Kunita, A.; Isogai, M.; Hibiya, T.; Ushiku, T.; Takada, K.; Fukayama, M. Profiling of Virus-Encoded MicroRNAs in Epstein-Barr Virus-Associated Gastric Carcinoma and Their Roles in Gastric Carcinogenesis. J. Virol. 2015, 89, 5581-5591. [CrossRef]

180. Gallo, A.; Vella, S.; Miele, M.; Timoneri, F.; Di Bella, M.; Bosi, S.; Sciveres, M.; Conaldi, P.G. Global profiling of viral and cellular non-coding RNAs in Epstein-Barr virus-induced lymphoblastoid cell lines and released exosome cargos. Cancer Lett. 2017, 388, 334-343. [CrossRef]

181. Verweij, F.; Van Eijndhoven, M.A.J.; Hopmans, E.S.; Vendrig, T.; Wurdinger, T.; Cahir-McFarland, E.; Kieff, E.; Geerts, D.; van der Kant, R.; Neefjes, J.; et al. LMP1 association with CD63 in endosomes and secretion via exosomes limits constitutive NF- $k B$ activation. EMBO J. 2011, 30, 2115-2129. [CrossRef] [PubMed]

182. Iwakiri, D.; Zhou, L.; Samanta, M.; Matsumoto, M.; Ebihara, T.; Seya, T.; Imai, S.; Fujieda, M.; Kawa, K.; Takada, K. Epstein-Barr virus (EBV)-encoded small RNA is released from EBV-infected cells and activates signaling from toll-like receptor 3. J. Exp. Med. 2009, 206, 2091-2099. [CrossRef]

183. Wu, L.; KewalRamani, V.N. Dendritic-cell interactions with HIV: Infection and viral dissemination. Nat. Rev. Immunol. 2006, 6, 859-868. [CrossRef] [PubMed]

184. Fang, Y.; Wu, N.; Gan, X.; Yan, W.; Morrell, J.C.; Gould, S.J. Higher-Order Oligomerization Targets Plasma Membrane Proteins and HIV Gag to Exosomes. PLoS Biol. 2007, 5, e158. [CrossRef]

185. Lenassi, M.; Cagney, G.; Liao, M.; Vaupotič, T.; Bartholomeeusen, K.; Cheng, Y.; Krogan, N.J.; Plemenitaš, A.; Peterlin, B. HIV Nef is secreted in exosomes and triggers apoptosis in bystander CD4+ T cells. Traffic 2010, 11, 110-122. [CrossRef]

186. De Carvalho, J.V.; de Castro, R.O.; da Silva, E.Z.; Silveira, P.P.; da Silva-Januário, M.E.; Arruda, E.; Jamur, M.C.; Oliver, C.; Aguiar, R.S.; DaSilva, L.L. Nef neutralizes the ability of exosomes from CD4+ T cells to act as decoys during HIV-1 infection. PLoS ONE 2014, 9, e113691. [CrossRef]

187. Bernard, M.; Zhao, H.; Yue, S.C.; Anandaiah, A.; Koziel, H.; Tachado, S.D. Novel HIV-1 MiRNAs Stimulate TNF $\alpha$ Release in Human Macrophages via TLR8 Signaling Pathway. PLoS ONE 2014, 9, e106006. [CrossRef]

188. Narayanan, A.; Iordanskiy, S.; Das, R.; Van Duyne, R.; Santos, S.; Jaworski, E.; Guendel, I.; Sampey, G.; Dalby, E.; Iglesias-Ussel, M.; et al. Exosomes Derived from HIV-1-infected Cells Contain Trans-activation Response Element RNA. J. Biol. Chem. 2013, 288, 20014-20033. [CrossRef]

189. Arenaccio, C.; Chiozzini, C.; Columba-Cabezas, S.; Manfredi, F.; Federico, M. Cell activation and HIV-1 replication in unstimulated CD4+ T lymphocytes ingesting exosomes from cells expressing defective HIV-1. Retrovirology 2014, 11, 1-16. [CrossRef]

190. Arenaccio, C.; Chiozzini, C.; Columba-Cabezas, S.; Manfredi, F.; Affabris, E.; Baur, A.; Federico, M. Exosomes from Human Immunodeficiency Virus Type 1 (HIV-1)-Infected Cells License Quiescent CD4 + T Lymphocytes to Replicate HIV-1 through a Nef- and ADAM17-Dependent Mechanism. J. Virol. 2014, 88, 11529-11539. [CrossRef]

191. Izquierdo-Useros, N.; Naranjo-Gomez, M.; Archer, J.; Hatch, S.C.; Erkizia, I.; Blanco, J.; Borras, F.E.; Puertas, M.C.; Connor, J.; Fernández-Figueras, M.T.; et al. Capture and transfer of HIV-1 particles by mature dendritic cells converges with the exosome-dissemination pathway. Blood J. Am. Soc. Hematol. 2009, 113, 2732-2741. [CrossRef]

192. Jolly, C.; Sattentau, Q.J. Human Immunodeficiency Virus Type 1 Assembly, Budding, and Cell-Cell Spread in T Cells Take Place in Tetraspanin-Enriched Plasma Membrane Domains. J. Virol. 2007, 81, 7873-7884. [CrossRef]

193. Mack, M.; Kleinschmidt, A.; Brühl, H.; Klier, C.; Nelson, P.J.; Cihak, J.; Plachý, J.; Stangassinger, M.; Erfle, V.; Schlöndorff, D. Transfer of the chemokine receptor CCR5 between cells by membrane-derived microparticles: A mechanism for cellular human immunodeficiency virus 1 infection. Nat. Med. 2000, 6, 769-775. [CrossRef]

194. Rozmyslowicz, T.; Majka, M.; Kijowski, J.; Murphy, S.L.; Conover, D.O.; Poncz, M.; Ratajczak, J.; Gaulton, G.N.; Ratajczak, M.Z. Platelet- and megakaryocyte-derived microparticles transfer CXCR4 receptor to CXCR4-null cells and make them susceptible to infection by X4-HIV. AIDS 2003, 17, 33-42. [CrossRef]

195. Narayanan, A.; Jaworski, E.; Van Duyne, R.; Iordanskiy, S.; Guendel, I.; Das, R.; Currer, R.; Sampey, G.; Chung, M.; Kehn-Hall, K.; et al. Exosomes derived from HTLV-1 infected cells contain the viral protein Tax. Retrovirology 2014, 11, O46. [CrossRef]

196. Anderson, M.; Lepene, B.; Kashanchi, F.; Jacobson, S. Detection of Human T-Cell Lymphotropic Virus Type I Proteins in Exosomes from HAM/TSP Patient CSF by Novel Nanotrap Technology (S12. 007); AAN Enterprises: Faridabad, India, 2015.

197. Chivero, E.T.; Bhattarai, N.; Rydze, R.T.; Winters, M.A.; Holodniy, M.; Stapleton, J.T. Human pegivirus RNA is found in multiple blood mononuclear cells in vivo and serum-derived viral RNA-containing particles are infectious in vitro. J. Gen. Virol. 2014, 95, 1307. [CrossRef] [PubMed]

198. Fleming, A.; Sampey, G.; Chung, M.-C.; Bailey, C.; Van Hoek, M.; Kashanchi, F.; Hakami, R.M. The carrying pigeons of the cell: Exosomes and their role in infectious diseases caused by human pathogens. Pathog. Dis. 2014, 71, 109-120. [CrossRef] [PubMed]

199. Nanbo, A.; Kawanishi, E.; Yoshida, R.; Yoshiyama, H. Exosomes Derived from Epstein-Barr Virus-Infected Cells Are Internalized via Caveola-Dependent Endocytosis and Promote Phenotypic Modulation in Target Cells. J. Virol. 2013, 87, 10334-10347. [CrossRef] 
200. Keryer-Bibens, C.; Pioche-Durieu, C.; Villemant, C.; Souquère, S.; Nishi, N.; Hirashima, M.; Middeldorp, J.; Busson, P. Exosomes released by EBV-infected nasopharyngeal carcinoma cells convey the viral Latent Membrane Protein 1 and the immunomodulatory protein galectin 9. BMC Cancer 2006, 6, 1-8. [CrossRef]

201. Klinker, M.W.; Lizzio, V.; Reed, T.J.; Fox, D.A.; Lundy, S.K. Human B cell-derived lymphoblastoid cell lines constitutively produce Fas ligand and secrete MHCII+ FasL+ killer exosomes. Front. Immunol. 2014, 5, 144. [CrossRef]

202. Klibi, J.; Niki, T.; Adhikary, D.; Mautner, J.; Busson, P.; Riedel, A.; Pioche-Durieu, C.; Souquere, S.; Rubinstein, E.; Le Moulec, S.; et al. Blood diffusion and Th1-suppressive effects of galectin-9-containing exosomes released by Epstein-Barr virus-infected nasopharyngeal carcinoma cells. Blood J. Am. Soc. Hematol. 2009, 113, 1957-1966. [CrossRef]

203. Wang, D.; Liebowitz, D.; Kieff, E. An EBV membrane protein expressed in immortalized lymphocytes transforms established rodent cells. Cell 1985, 43, 831-840. [CrossRef]

204. Mosialos, G.; Birkenbacht, M.; Yalamanchill, R.; Van Arsdale, T.; Ware, C.; Kleff, E. The Epstein-Barr virus transforming protein LMP1 engages signaling proteins for the tumor necrosis factor receptor family. Cell 1995, 80, 389-399. [CrossRef]

205. Lavorgna, A.; Harhaj, E.W. EBV LMP1: New and shared pathways to NF-кB activation. Proc. Natl. Acad. Sci. USA 2012, 109, 2188-2189. [CrossRef]

206. Longnecker, R.; Kieff, E. A second Epstein-Barr virus membrane protein (LMP2) is expressed in latent infection and colocalizes with LMP1. J. Virol. 1990, 64, 2319-2326. [CrossRef]

207. Caldwell, R.G.; Wilson, J.B.; Anderson, S.J.; Longnecker, R. Epstein-Barr Virus LMP2A Drives B Cell Development and Survival in the Absence of Normal B Cell Receptor Signals. Immunity 1998, 9, 405-411. [CrossRef]

208. Casola, S.; Otipoby, K.L.; Alimzhanov, M.; Humme, S.; Uyttersprot, N.; Kutok, J.L.; Carroll, M.C.; Rajewsky, K. B cell receptor signal strength determines B cell fate. Nat. Immunol. 2004, 5, 317-327. [CrossRef]

209. Oldstone, M.B. Viral persistence: Parameters, mechanisms and future predictions. Virology 2006, 344, 111-118. [CrossRef] [PubMed]

210. Cox, J.E.; Sullivan, C.S. Balance and Stealth: The Role of Noncoding RNAs in the Regulation of Virus Gene Expression. Annu. Rev. Virol. 2014, 1, 89-109. [CrossRef] [PubMed]

211. Nicoll, M.; Proença, J.; Efstathiou, S. The molecular basis of herpes simplex virus latency. FEMS Microbiol. Rev. 2012, 36, 684-705. [CrossRef]

212. Umbach, J.L.; Kramer, M.F.; Jurak, I.; Karnowski, H.W.; Coen, D.M.; Cullen, B.R. MicroRNAs expressed by herpes simplex virus 1 during latent infection regulate viral mRNAs. Nature 2008, 454, 780-783. [CrossRef]

213. Du, T.; Han, Z.; Zhou, G.; Roizman, B. Patterns of accumulation of miRNAs encoded by herpes simplex virus during productive infection, latency, and on reactivation. Proc. Natl. Acad. Sci. USA 2015, 112, E49-E55. [CrossRef]

214. Piedade, D.; Azevedo-Pereira, J.M. The Role of microRNAs in the Pathogenesis of Herpesvirus Infection. Viruses 2016, 8, 156. [CrossRef] [PubMed]

215. Han, Z.; Liu, X.; Chen, X.; Zhou, X.; Du, T.; Roizman, B.; Zhou, G. miR-H28 and miR-H29 expressed late in productive infection are exported and restrict HSV-1 replication and spread in recipient cells. Proc. Natl. Acad. Sci. USA 2016, 113, E894-E901. [CrossRef]

216. Mclauchlan, J.; Addison, C.; Craigie, M.C.; Rixon, F.J. Noninfectious L-particles supply functions which can facilitate infection by HSV-1. Virology 1992, 190, 682-688. [CrossRef]

217. Rixon, F.J.; Addison, C.; Mclauchlan, J. Assembly of enveloped tegument structures (L particles) can occur independently of virion maturation in herpes simplex virus type 1-infected cells. J. Gen. Virol. 1992, 73, 277-284. [CrossRef]

218. Heilingloh, C.S.; Kummer, M.; Mühl-Zürbes, P.; Drassner, C.; Daniel, C.; Klewer, M.; Steinkasserer, A. L Particles Transmit Viral Proteins from Herpes Simplex Virus 1-Infected Mature Dendritic Cells to Uninfected Bystander Cells, Inducing CD83 Downmodulation. J. Virol. 2015, 89, 11046-11055. [CrossRef]

219. Chen, R.; Zhao, X.; Wang, Y.; Xie, Y.; Liu, J. Hepatitis B virus X protein is capable of down-regulating protein level of host antiviral protein APOBEC3G. Sci. Rep. 2017, 7, 1-10. [CrossRef] [PubMed]

220. Chai, N.; Chang, H.E.; Nicolas, E.; Han, Z.; Jarnik, M.; Taylor, J. Properties of Subviral Particles of Hepatitis B Virus. J. Virol. 2008, 82, 7812-7817. [CrossRef]

221. Kadiu, I.; Narayanasamy, P.; Dash, P.K.; Zhang, W.; Gendelman, H.E. Biochemical and Biologic Characterization of Exosomes and Microvesicles as Facilitators of HIV-1 Infection in Macrophages. J. Immunol. 2012, 189, 744-754. [CrossRef] [PubMed]

222. Konadu, K.A.; Chu, J.; Huang, M.B.; Amancha, P.K.; Armstrong, W.S.; Powell, M.D.; Villinger, F.; Bond, V.C. Association of Cytokines with Exosomes in the Plasma of HIV-1-Seropositive Individuals. J. Infect. Dis. 2015, 211, 1712-1716. [CrossRef]

223. Esser, M.T.; Graham, D.R.; Coren, L.V.; Trubey, C.M.; Bess, J.W.; Arthur, L.O.; Ott, D.E.; Lifson, J.D. Differential Incorporation of CD45, CD80 (B7-1), CD86 (B7-2), and Major Histocompatibility Complex Class I and II Molecules into Human Immunodeficiency Virus Type 1 Virions and Microvesicles: Implications for Viral Pathogenesis and Immune Regulation. J. Virol. 2001, 75, 6173-6182. [CrossRef]

224. Tumne, A.; Prasad, V.S.; Chen, Y.; Stolz, D.B.; Saha, K.; Ratner, D.M.; Ding, M.; Watkins, S.C.; Gupta, P. Noncytotoxic suppression of human immunodeficiency virus type 1 transcription by exosomes secreted from CD8+ T cells. J. Virol. 2009, 83, 4354-4364. [CrossRef] [PubMed]

225. Khatua, A.K.; Taylor, H.E.; Hildreth, J.E.K.; Popik, W. Exosomes Packaging APOBEC3G Confer Human Immunodeficiency Virus Resistance to Recipient Cells. J. Virol. 2009, 83, 512-521. [CrossRef] [PubMed] 
226. Liu, Z.; Zhang, X.; Yu, Q.; He, J.J. Exosome-associated hepatitis C virus in cell cultures and patient plasma. Biochem. Biophys. Res. Commun. 2014, 455, 218-222. [CrossRef] [PubMed]

227. Badierah, R.A.; Uversky, V.N.; Redwan, E.M. Dancing with Trojan horses: An interplay between the extracellular vesicles and viruses. J. Biomol. Struct. Dyn. 2020, 39, 1-27. [CrossRef]

228. Elrashdy, F.; Aljaddawi, A.A.; Redwan, E.M.; Uversky, V.N. On the potential role of exosomes in the COVID-19 reinfection/reactivation opportunity. J. Biomol. Struct. Dyn. 2021, 39, 5831-5842. [CrossRef]

229. Zhang, C.; Shi, L.; Wang, F.-S. Liver injury in COVID-19: Management and challenges. Lancet Gastroenterol. Hepatol. 2020, 5, 428-430. [CrossRef]

230. Zhang, X.-J.; Qin, J.-J.; Cheng, X.; Shen, L.; Zhao, Y.-C.; Yuan, Y.; Lei, F.; Chen, M.-M.; Yang, H.; Bai, L.; et al. In-hospital use of statins is associated with a reduced risk of mortality among individuals with COVID-19. Cell Metab. 2020, 32, 176-187. [CrossRef]

231. Song, J.-W.; Lam, S.M.; Fan, X.; Cao, W.-J.; Wang, S.-Y.; Tian, H.; Chua, G.H.; Zhang, C.; Meng, F.-P.; Xu, Z.; et al. Omics-Driven Systems Interrogation of Metabolic Dysregulation in COVID-19 Pathogenesis. Cell Metab. 2020, 32, 188-202. [CrossRef]

232. Song, Y.; Liu, P.; Shi, X.L.; Chu, Y.L.; Zhang, J.; Xia, J.; Gao, X.Z.; Qu, T.; Wang, M.Y. SARS-CoV-2 induced diarrhoea as onset symptom in patient with COVID-19. Gut 2020,69, 1143-1144. [CrossRef]

233. Kwon, Y.; Nukala, S.B.; Srivastava, S.; Miyamoto, H.; Ismail, N.I.; Ong, S.-B.; Lee, W.H.; Ong, S. Detection of Viral RNA Fragments in Human iPSC-Cardiomyocytes following Treatment with Extracellular Vesicles from SARS-CoV-2 Coding-SequenceOverexpressing Lung Epithelial Cells. bioRxiv 2020. [CrossRef]

234. Bouhaddou, M.; Memon, D.; Meyer, B.; White, K.M.; Rezelj, V.V.; Marrero, M.C.; Polacco, B.J.; Melnyk, J.E.; Ulferts, S.; Kaake, R.M.; et al. The global phosphorylation landscape of SARS-CoV-2 infection. Cell 2020, 182, 685-712. [CrossRef]

235. Qian, Z.; Travanty, E.A.; Oko, L.; Edeen, K.; Berglund, A.; Wang, J.; Ito, Y.; Holmes, K.V.; Mason, R.J. Innate Immune Response of Human Alveolar Type II Cells Infected with Severe Acute Respiratory Syndrome-Coronavirus. Am. J. Respir. Cell Mol. Biol. 2013, 48, 742-748. [CrossRef] [PubMed]

236. Uversky, V.N.; Elrashdy, F.; Aljadawi, A.; Ali, S.M.; Khan, R.H.; Redwan, E.M. Severe acute respiratory syndrome coronavirus 2 infection reaches the human nervous system: How? J. Neurosci. Res. 2020, 99, 750-777. [CrossRef]

237. Su, H.; Yang, M.; Wan, C.; Yi, L.-X.; Tang, F.; Zhu, H.-Y.; Yi, F.; Yang, H.-C.; Fogo, A.B.; Nie, X.; et al. Renal histopathological analysis of 26 postmortem findings of patients with COVID-19 in China. Kidney Int. 2020, 98, 219-227. [CrossRef]

238. Farkash, E.A.; Wilson, A.M.; Jentzen, J.M. Ultrastructural evidence for direct renal infection with SARS-CoV-2. J. Am. Soc. Nephrol. 2020, 31, 1683-1687. [CrossRef]

239. Ling, Y.; Xu, S.-B.; Lin, Y.-X.; Tian, D.; Zhu, Z.-Q.; Dai, F.-H.; Wu, F.; Song, Z.-G.; Huang, W.; Chen, J.; et al. Persistence and clearance of viral RNA in 2019 novel coronavirus disease rehabilitation patients. Chin. Med. J. 2020, 133, 1039-1043. [CrossRef] [PubMed]

240. Wang, W.; Xu, Y.; Gao, R.; Lu, R.; Han, K.; Wu, G.; Tan, W. Detection of SARS-CoV-2 in different types of clinical specimens. JAMA 2020, 323, 1843-1844. [CrossRef]

241. Mason, R.J. Pathogenesis of COVID-19 from a cell biology perspective. Eur. Respir. J. 2020, 55, 2000607. [CrossRef]

242. Mönkemüller, K.; Fry, L.; Rickes, S. COVID-19, coronavirus, SARS-CoV-2 and the small bowel. Rev. Esp. Enferm. Dig. 2020, 112, 383-388.

243. Monteil, V.; Kwon, H.; Prado, P.; Hagelkrüys, A.; Wimmer, R.A.; Stahl, M.; Leopoldi, A.; Garreta, E.; del Pozo, C.H.; Prosper, F.; et al. Inhibition of SARS-CoV-2 infections in engineered human tissues using clinical-grade soluble human ACE2. Cell 2020, 181, 905-913.e7. [CrossRef] [PubMed]

244. Varga, Z.; Flammer, A.J.; Steiger, P.; Haberecker, M.; Andermatt, R.; Zinkernagel, A.S.; Mehra, M.R.; Schuepbach, R.A.; Ruschitzka, F.; Moch, H. Endothelial cell infection and endotheliitis in COVID-19. Lancet 2020, 395, 10234. [CrossRef]

245. Knoops, K.; Kikkert, M.; Worm, S.H.E.V.D.; Zevenhoven-Dobbe, J.C.; Van Der Meer, Y.; Koster, A.J.; Mommaas, A.M.; Snijder, E.J. SARS-Coronavirus Replication Is Supported by a Reticulovesicular Network of Modified Endoplasmic Reticulum. PLoS Biol. 2008, 6, e226. [CrossRef]

246. Knoops, K.; Barcena, M.; Limpens, R.; Koster, A.; Mommaas, A.M.; Snijder, E.J. Ultrastructural Characterization of Arterivirus Replication Structures: Reshaping the Endoplasmic Reticulum To Accommodate Viral RNA Synthesis. J. Virol. 2012, 86, $2474-2487$. [CrossRef]

247. El-Fakharany, E.M.; El-Maradny, Y.; Othman, A.; Gerges, M.; Belal, F.; Behery, E. COVID-19 coronavirus: Pathogenesis, clinical features, diagnostics, epidemiology, prevention and control. Microb. Biosyst. 2020, 5, 1-14. [CrossRef]

248. Al-Mulla, H.M.N.; Turrell, L.; Smith, N.M.; Payne, L.; Baliji, S.; Züst, R.; Thiel, V.; Baker, S.C.; Siddell, S.; Neuman, B.W. Competitive Fitness in Coronaviruses Is Not Correlated with Size or Number of Double-Membrane Vesicles under ReducedTemperature Growth Conditions. mBio 2014, 5, e01017-14. [CrossRef]

249. Angelini, M.M.; Akhlaghpour, M.; Neuman, B.W.; Buchmeier, M.J. Severe Acute Respiratory Syndrome Coronavirus Nonstructural Proteins 3, 4, and 6 Induce Double-Membrane Vesicles. mBio 2013, 4, e00524-13. [CrossRef]

250. Oudshoorn, D.; Rijs, K.; Limpens, R.; Groen, K.; Koster, A.J.; Snijder, E.J.; Kikkert, M.; Bárcena, M. Expression and Cleavage of Middle East Respiratory Syndrome Coronavirus nsp3-4 Polyprotein Induce the Formation of Double-Membrane Vesicles That Mimic Those Associated with Coronaviral RNA Replication. mBio 2017, 8, e01658-17. [CrossRef] [PubMed]

251. Li, J.; Liu, K.; Liu, Y.; Xu, Y.; Zhang, F.; Yang, H.; Liu, J.; Pan, T.; Chen, J.; Wu, M.; et al. Exosomes mediate the cell-to-cell transmission of IFN- $\alpha$-induced antiviral activity. Nat. Immunol. 2013, 14, 793-803. [CrossRef] 
252. Koppers-Lalic, D.; Hogenboom, M.M.; Middeldorp, J.; Pegtel, D.M. Virus-modified exosomes for targeted RNA delivery; A new approach in nanomedicine. Adv. Drug Deliv. Rev. 2013, 65, 348-356. [CrossRef] [PubMed]

253. Alvarez-Erviti, L.; Seow, Y.; Yin, H.; Betts, C.; Lakhal, S.; Wood, M.J.A. Delivery of siRNA to the mouse brain by systemic injection of targeted exosomes. Nat. Biotechnol. 2011, 29, 341-345. [CrossRef]

254. Viaud, S.; Théry, C.; Ploix, S.; Tursz, T.; Lapierre, V.; Lantz, O.; Zitvogel, L.; Chaput, N. Dendritic Cell-Derived Exosomes for Cancer Immunotherapy: What's Next? Cancer Res. 2010, 70, 1281-1285. [CrossRef]

255. Aline, F.; Bout, D.; Amigorena, S.; Roingeard, P.; Dimier-Poisson, I. Toxoplasma gondii Antigen-Pulsed-Dendritic Cell-Derived Exosomes Induce a Protective Immune Response against T. gondii Infection. Infect. Immun. 2004, 72, 4127-4137. [CrossRef] [PubMed]

256. Van den Boorn, J.G.; Schlee, M.; Coch, C.; Hartmann, G. SiRNA delivery with exosome nanoparticles. Nat. Biotechnol. 2011, 29, 325-326. [CrossRef] [PubMed]

257. Jesus, S.; Soares, E.; Cruz, M.T.; Borges, O. Exosomes as adjuvants for the recombinant hepatitis B antigen: First report. Eur. J. Pharm. Biopharm. 2018, 133, 1-11. [CrossRef]

258. Ferrantelli, F.; Manfredi, F.; Chiozzini, C.; Anticoli, S.; Olivetta, E.; Arenaccio, C.; Federico, M. DNA Vectors Generating Engineered Exosomes Potential CTL Vaccine Candidates Against AIDS, Hepatitis B, and Tumors. Mol. Biotechnol. 2018, 60, 773-782. [CrossRef]

259. Näslund, T.I.; Paquin-Proulx, D.; Paredes, P.T.; Vallhov, H.; Sandberg, J.K.; Gabrielsson, S. Exosomes from breast milk inhibit HIV-1 infection of dendritic cells and subsequent viral transfer to CD4+ T cells. AIDS 2014, 28, 171-180. [CrossRef] [PubMed]

260. Orleans, L.A.; Vice, H.; Manchikanti, L. Expanded umbilical cord mesenchymal stem cells (UC-MSCs) as a therapeutic strategy in managing critically ill COVID-19 patients: The case for compassionate use. Pain Physician 2020, 23, E71-E83.

261. Tsiapalis, D.; O'Driscoll, L. Mesenchymal Stem Cell Derived Extracellular Vesicles for Tissue Engineering and Regenerative Medicine Applications. Cells 2020, 9, 991. [CrossRef]

262. Bari, E.; Ferrarotti, I.; Torre, M.L.; Corsico, A.G.; Perteghella, S. Mesenchymal stem/stromal cell secretome for lung regeneration: The long way through "pharmaceuticalization" for the best formulation. J. Control. Release 2019, 309, 11-24. [CrossRef] [PubMed]

263. Bari, E.; Ferrarotti, I.; Saracino, L.; Perteghella, S.; Torre, M.L.; Corsico, A.G. Mesenchymal Stromal Cell Secretome for Severe COVID-19 Infections: Premises for the Therapeutic Use. Cells 2020, 9, 924. [CrossRef]

264. U.S. National Institutes of Health. 2019. Available online: https:/ / clinicaltrials.gov (accessed on 8 April 2020).

265. Canham, M.A.; Campbell, J.D.M.; Mountford, J.C. The use of mesenchymal stromal cells in the treatment of coronavirus disease 2019. J. Transl. Med. 2020, 18, 1-15. [CrossRef]

266. Khoury, M.; Cuenca, J.; Cruz, F.F.; Figueroa, F.E.; Rocco, P.R.M.; Weiss, D.J. Current status of cell-based therapies for respiratory virus infections: Applicability to COVID-19. Eur. Respir. J. 2020, 55, 2000858. [CrossRef]

267. Sengupta, V.; Sengupta, S.; Lazo, A.; Woods, P.; Nolan, A.; Bremer, N. Exosomes Derived from Bone Marrow Mesenchymal Stem Cells as Treatment for Severe COVID-19. Stem Cells Dev. 2020, 29, 747-754. [CrossRef] [PubMed]

268. Leng, Z.; Zhu, R.; Hou, W.; Feng, Y.; Yang, Y.; Han, Q.; Shan, G.; Meng, F.; Du, D.; Wang, S.; et al. Transplantation of ACE2Mesenchymal Stem Cells Improves the Outcome of Patients with COVID-19 Pneumonia. Aging Dis. 2020, 11, 216-228. [CrossRef]

269. NIH. A Pilot Clinical Study on Inhalation of Mesenchymal Stem Cells Exosomes Treating Severe Novel Coronavirus Pneumonia. Case Med Res. 2020. [CrossRef]

270. Alzahrani, F.A.; Saadeldin, I.M.; Ahmad, A.; Kumar, D.; Azhar, E.I.; Siddiqui, A.J.; Kurdi, B.; Sajini, A.; Alrefaei, A.F.; Jahan, S. The Potential Use of Mesenchymal Stem Cells and Their Derived Exosomes as Immunomodulatory Agents for COVID-19 Patients. Stem Cells Int. 2020, 2020, 1-11. [CrossRef] [PubMed]

271. Pocsfalvi, G.; Mammadova, R.; Ramos Juarez, A.P.; Bokka, R.; Trepiccione, F.; Capasso, G. COVID-19 and Extracellular Vesicles: An Intriguing Interplay. Kidney Blood Press. Res. 2020, 45, 661-670. [CrossRef]

272. Organicell Flow for Patients with COVID-19, NCT04384445. 2020. Available online: https:/ clinicaltrials.gov/show/NCT04384 445 (accessed on 12 May 2020).

273. Singh, S.; Chakravarty, T.; Chen, P.; Akhmerov, A.; Falk, J.; Friedman, O.; Zaman, T.; Ebinger, J.E.; Gheorghiu, M.; Marbán, L.; et al. Allogeneic cardiosphere-derived cells (CAP-1002) in critically ill COVID-19 patients: Compassionate-use case series. Basic Res. Cardiol. 2020, 115, 1-11. [CrossRef] [PubMed]

274. Evaluation of Safety and Efficiency of Method of Exosome Inhalation in SARS-CoV-2 Associated Pneumonia, NCT04491240. 2020. Available online: https:/ / clinicaltrials.gov / show / NCT04491240 (accessed on 29 July 2020). 